\title{
NOVOS DADOS SOBRE OS HIPOGEUS DO BRONZE PLENO DE TORRE VELHA 3 (SERPA): CONTEXTOS SEPULCRAIS E ESTUDO DO ESPÓLIO OSTEOLÓGICO HUMANO
}

\author{
DANIEL FERREIRA FIDALGO ${ }^{(1)}$, EDUARDO PORFÍRIO $^{(2)}$ \& ANA MARIA SILVA $^{(3)}$
}

Resumo:

Abstract:

\begin{abstract}
O presente trabalho incide sobre a análise antropológica do espólio ósseo humano recuperado de 21 hipogeus do arqueossítio de Torre Velha 3 (TV3; São Salvador, Serpa), datados entre os meados e a segunda metade do II milénio a.C.. Dezasseis hipogeus são individuais, três duplos (uma inumação in situ com uma redução associada) e um triplo (enterramento duplo com uma redução associada) e dois contextos funerários inconclusivos. Todos os restos ósseos humanos foram recuperados da câmara funerária. Para além destes, um hipogeu continha um enterramento com uma redução associada na câmara e uma inumação primária na antecâmara. Destes sepulcros foram exumados 28 indivíduos, 22 adultos (11 do sexo feminino, nove do masculino e dois casos indeterminados), cinco não adultos e um em que não foi possível atribuir uma faixa etária.

Nas inumações primárias e individuais, as oferendas cárneas encontram-se associadas a adultos de ambos os sexos. Por sua vez as cerâmicas e punções surgem somente em enterramentos do sexo feminino, com a excepção de um punção associado ao adulto do sexo masculino [2007].

Recorrendo à análise estatística de componentes principais, foi possível observar que as diferenças na morfologia dentária de TV3 em comparação com outras amostras da Pré-História recente Peninsular são mínimas, e podem ser explicadas por mudanças genéticas associadas a possíveis contactos e interações interregionais.

Foram ainda identificados padrões de desgaste dentário atípico que sugerem o uso parafuncional do sistema mastigatório de adultos do sexo feminino. Relativamente à patologia oral, a incidência de lesões cariogénicas na amostra é de 5,85\% (29/495), e afecta cerca de $57 \%$ dos indivíduos analisados $(n=21)$. Estes valores são superiores à maioria das amostras comparadas do Neolítico Final/Calcolítico do actual território Português, mas semelhantes aos registados para outras comunidades da Idade do Bronze.
\end{abstract}

Palavras-Chave: Idade do Bronze, Restos ósseos humanos, Práticas Funerárias, uso não mastigatório de dentes.

New data on the Middle Bronze Age hypogea of Torre Velha 3 (Serpa): burial contexts and the study of the human osteological remains

The present work focuses on the anthropological analysis of the human remains exhumed from 21 hypogea of the archaeological site of Torre Velha 3 (TV3; São Salvador, Serpa), which is dated between the middle and second half of the II millennium B.C. Sixteen hypogea were individual, three double (one in situ burial with an associated reduction) and one triple (double burial with associated reduction) and two inconclusive funerary contexts. The human remains were collected unearthed from the chambers of the tombs. Besides these, one hypogeum displayed an in situ burial with an associated reduction in the chamber and other in situ burial in the antechamber. From these tombs were exhumed 28 individuals, 22 adults (11 females, nine males and 2 inconclusive), five non adults and one unknown.

In primary and individual burials, meat offering were found in association with adults from both sexes. Ceramic vessels and awls are found only in female burials, with the exception of one awl found in association with the male adult [2007].

Using a principal component analyses, it was possible to observe that the differences in dental morphological traits found in TV3, in comparison with other samples from the Iberian Peninsula's recent pre-history, are minimal and can be explained by genetic changes derived from possible inter-regional contacts and interactions. Some atypical dental wear patterns were also identified, mostly in adult females, and these suggest the parafunctional use of the masticatory system. Finally, the incidence of cariogenic lesions found is $5.85 \%$ $(29 / 495)$, affecting around $57 \%$ of the individuals analysed $(n=21)$. These values are higher than Late Neolithic/ Chalcolithic samples from nowadays Portugal, but similar to the values found in Bronze Age samples.

Keywords: Bronze Age; Human remains; Funerary Practices; tooth-tool use.

Received: 31 January, 2016; Accepted: 24 April, 2016

\section{INTRODUÇÃO}

$\mathrm{O}$ arqueossítio Torre Velha 3 (TV3) foi identificado nas intervenções arqueológicas realizadas no âmbito da Minimização de Impactes decorrentes da Construção da Barragem da Laje (Serpa), um projecto integrado no Empreendimento de Fins Múltiplos do Alqueva, da responsabilidade da Empresa de Desenvolvimento e Infra-Estruturas do Alqueva S.A. (EDIA) (ALVES et al. 2010).

\footnotetext{
${ }^{(1)}$ Departamento das Ciências da Vida da FCTUC - Faculdade de Ciências e Tecnologia da Universidade de Coimbra; CIAS - Centro de Investigação em Antropologia e Saúde; Fundação Araporã. Email do autor correspondente: danielfidalgo15@gmail.com

pologia e Saúde; Fundação Araporã. Email do autor correspondente: danielfidalgo15@gmail.com
${ }^{(2)}$ Palimpsesto - Estudo e Preservação do Património Cultural Lda. Email: eduardoporfirio@palimpsesto.pt

${ }^{(3)}$ Departamento das Ciências da Vida da FCTUC - Faculdade de Ciências e Tecnologia da Universidade de Coimbra; CIAS - Centro de Investigação em Antropologia e Saúde; UNIARQ - Centro de Arqueologia da Universidade de Lisboa. Email: amgsilva@antrop.uc.pt
} 
Duas campanhas foram realizadas entre Dezembro de 2008 e Abril de 2009, cobrindo uma área aproximadamente de $13840 \mathrm{~m}^{2}$ (ALVES et al. 2012). Ambas foram efectuadas pela empresa Palimpsesto - Estudo e Preservação do Património Cultural Lda. (AlVES et al. 2009), ficando o levantamento dos dados antropológicos a cargo da empresa Styx, Estudos de Antropologia, Lda. (FERREIRA 2009).

Concluídas as intervenções, foram identificadas 589 estruturas arqueológicas revelando uma vasta diacronia ocupacional que, com alguns hiatos temporais entre si, se estende desde o Calcolítico até à Antiguidade Tardia (ALves et al. 2014).
Entre os vestígios mais relevantes resgatados nesta intervenção arqueológica, está uma necrópole datada do Bronze Pleno composta por 25 hipogeus, cronologia corroborada por várias datações de radiocarbono (Tabela 1). Em 2014, os remanescentes osteológicos humanos identificados nesta necrópole foram conduzidos para o Departamento de Ciências da Vida da Universidade de Coimbra para serem alvos de análise laboratorial (FIDALGO 2014). Este trabalho apresenta, de forma mais sumária, alguns dos resultados obtidos nessa mesma análise.

Tabela 1. Datações por radiocarbono para os Hipogeus de Torre Velha 3. IntCal atmospheric Curve (REIMER et al. 2004). (Adaptado de AlVes et al. 2010: Tabela 3; VALÉRIO et al. 2014: Tabela 1).

Table 1. Radiocarbon datings for the Hypogea of Torre Velha 3. IntCal atmospheric Curve (REIMER et al. 2004). (Adapted from ALVES et al. 2010: Table 3; VALÉRIO et al. 2014: Table 1).

\begin{tabular}{|c|c|c|c|c|c|c|}
\hline \multirow{2}{*}{ Ref. Lab. } & \multirow{2}{*}{ Estrutura } & \multirow{2}{*}{ Tipo Amostra } & \multirow{2}{*}{$\delta^{13} \mathrm{C}(\%)$} & \multirow{2}{*}{${ }^{14} \mathrm{C}$ (BP) } & \multicolumn{2}{|c|}{ Cal. a.C } \\
\hline & & & & & $1 \sigma$ & $2 \sigma$ \\
\hline Sac. -2825 & {$[1267]-[1792]$} & Osso humano & -20.3 & $3280 \pm 50$ & $1610-1500$ & $1680-1450$ \\
\hline Sac. -2489 & {$[1489]-[1490]$} & Bos (rádio) & -22.3 & $3300 \pm 45$ & $1630-1510$ & $1690-1450$ \\
\hline Beta - 262199 & {$[1662]-[1664]$} & Ovis (rádio) & -20.5 & $3300 \pm 40$ & $1630-1520$ & $1690-1490$ \\
\hline Sac. -2490 & {$[1949]-[1959]$} & Bos (rádio; ulna) & -21.5 & $3410 \pm 60$ & $1870-1620$ & $1890-1530$ \\
\hline Sac. -2465 & {$[2119]-[2120]$} & Bos (rádio; ulna) & -22.0 & $3300 \pm 50$ & $1614-1510$ & $1730-1450$ \\
\hline Sac. -2827 & {$[2356]-[2357]$} & Osso humano & -20.3 & $3340 \pm 80$ & $1700-1520$ & $1780-1440$ \\
\hline Sac. -2826 & {$[2417]-[2418]$} & Osso humano & -20.5 & $3170 \pm 90$ & $1530-1320$ & $1670-1250$ \\
\hline Sac. -2480 & {$[2498]-[2497]$} & Bos (rádio) & -21.5 & $3410 \pm 60$ & $1870-1620$ & $1890-1530$ \\
\hline Sac. -2466 & {$[2550]-[2551]$} & Bos (rádio) & -21.8 & $3250 \pm 60$ & $1610-1450$ & $1670-1410$ \\
\hline Sac. -2883 & [1991] & Osso humano & -20.6 & $3290 \pm 50$ & $1620-1510$ & $1690-1450$ \\
\hline
\end{tabular}

\section{CONTEXTO GEOGRÁFICO E INTERVENÇÃO ARQUEOLÓGICA}

O sítio arqueológico de TV3 situa-se na Herdade da Torre Velha, na extinta freguesia de São Salvador, concelho de Serpa, distrito de Beja. As coordenadas geográficas são M-253962,711; P111569,121 (sistema de projeção Hayford-Gauss, Datum 73) segundo a Carta Militar de Portugal, folha $n^{\circ} 523$, na escala 1:25 000 (Fig. 1). Encontrase a $10 \mathrm{~km}$ a Este de Serpa, ocupando uma elevação suave (altitude média de 180 metros), com as vertentes mais acentuadas localizadas no quadrante Norte e Oeste (ALVES et al. 2010). Este tipo de relevo é característico da peneplanície alentejana, caracterizada por uma grande homogeneidade patente tanto ao nível da morfologia - uma sucessão de colinas onduladas, como ao nível das cotas altimétricas - cujas altitudes máximas se situam entre os 200 e os 230 metros (ALVES et al. 2012). A Norte e Este, o espaço é delimitado pelo Barranco da Laje, afluente da Ribeira do Enxoé (PORFÍrIo \& SERRA 2010; ESTRELA et al. 2012).

\section{OS HIPOGEUS NO BRONZE DO SUDOESTE}

Os hipogeus são estruturas sepulcrais escavadas na rocha, reconhecidas no registo arqueológico Peninsular desde o Neolítico (RIVERO GALAN 1988). De um modo geral, são caracterizados como espaços de inumações colectivas, cujas evidências sugerem que tenham sido utilizados ao longo de uma ampla diacronia (SOARES et al. 2009; SILVA 2012). No decorrer do II milénio a.C., na região do Sudoeste Peninsular, esta antiga tradição é, de certo modo, recuperada. Contudo, apresentam características e contextos diferentes dos seus anteriores, entre as quais se destaca: (i) a organização espacial e arquitectónica, que se altera para um espaço de menores dimensões, fenómeno que pode ser enquadrado naquilo que García Sanjuán (2006) define como desmonumentalização; (ii) o declínio das inumações colectivas em prol de inumações individuais e duplas, ainda que com frequentes sinais de reutilização; (iii) Subjacente à individualização das inumações está a presença frequente de espólios votivos (cerâmica, artefactos metálicos e restos osteológicos faunísticos) que, ao aparecerem associados ao indivíduo inumado, são portadores de um 


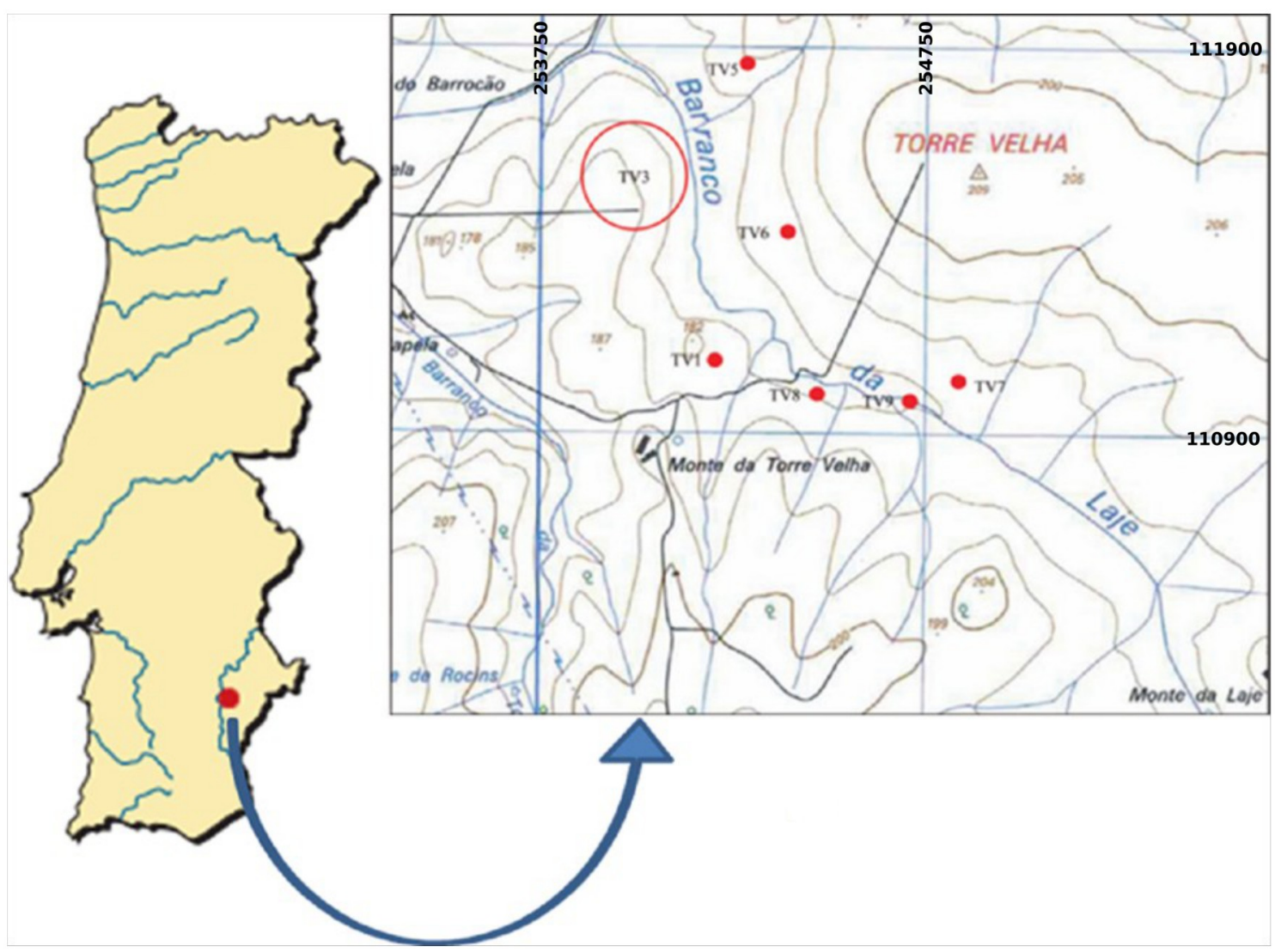

Fig. 1. Serpa no mapa de Portugal (Alves et al. 2012: 31) e localização de Torre Velha 3 na Carta Militar de Portugal n523, escala 1/25000 (ESTRELA et al. 2012: 237).

Fig. 1. Serpa in the map of Portugal (Alves et al. 2012:31) and the location of Torre Velha 3 on the Carta Militar de Portugal n523, scale 1/25000 (ESTRELA et al. 2012:237).

grande potencial informativo. Não só sobre os valores simbólicos e as ritualizações que rodeiam o mundo da morte, mas também sobre a posição que o indivíduo terá ocupado na comunidade, pois a grande maioria do espólio funerário é constituída por elementos do quotidiano, o que permite lançar alguma luz sobre o seu estatuto social e laboral, incluindo as questões relativas à diferenciação sexual (ARANDA JiMÉNEZ \& ESQUIVEL GUERRERO 2006).

Os hipogeus do Bronze do Sudoeste tendem frequentemente a aparecer em aglomerados, podendo por vezes estar subdivididos em vários núcleos dentro de uma mesma necrópole e, em sincronia com estruturas de outras tipologias escavadas no substrato geológico das quais algumas apresentam também utilização funerária (ALVES et al. 2010). Vários autores como Mariano del Amo y de la Hera (1993) avançaram com a hipótese de que as aglomerações de cistas do Bronze do Sudoeste puderem reflectir estruturas sociais baseadas no parentesco. Também para as necrópoles de hipogeus recentemente identificadas na região do Baixo Alentejo será possível extrapolar a mesma organização social ou uma semelhante (PORFíRIO \& SERRA 2010). Possivelmente, a decisão de enterrar um indivíduo num hipogeu, numa cista ou numa fossa pode em si ser evidência de uma ou mais divisões hierárquicas ou de parentesco existentes dentro de uma determinada comunidade. Tal premissa viria contribuir para interpretar a razão que está subjacente à reutilização de um espaço sepulcral.

O primeiro hipogeu da Idade do Bronze identificado no Sudoeste foi a sepultura de Belmeque. $\mathrm{Na}$ época constituía um caso isolado sendo considerado um elemento exógeno na cultura da Idade do Bronze do Sudoeste da Península Ibérica pelo seu espólio e pela sua arquitectura, cujos paralelos para esta última eram apenas reconhecíveis no Sudeste Peninsular, atribuindo-lhe assim, até certo ponto, uma influência argárica (SCHUBART 1971; SOARES 1994). Nos finais do século passado e nos inícios do actual, intensificaram-se os estudos arqueológicos na margem esquerda portuguesa do rio Guadiana, devido essencialmente ao aumento de projectos de minimização de impactos patrimoniais, que resultaram na identificação de novos contextos relacionados com hipogeus da Idade do Bronze. Além de TV3, destacam-se os arqueossítios de Alto de Brinches 3 (Rodrigues et al. 2012), Monte do Gato de Cima 3/ Outeiro Alto 2 (VALERA \& FILIPE 2010; FILIPE et al. 2013; TOMÉ et al. 2014), Montinhos 6 (BAPTISTA et al. 2012; COSTA \& BAPTISTA 2014), Torre Velha 12 (GOMES et al. 2013) e Horta do Folgão (VALÉRIO et al. 2012; PONTE et al. 2012). 


\subsection{Os hipogeus de Torre Velha 3}

Os hipogeus de TV3 encontram-se subdivididos em dois núcleos principais: $\mathrm{O}$ primeiro composto por 20 hipogeus e o segundo por cinco hipogeus (Alves et al. 2010; PORFíRIO 2014). O hipogeu [2236] - [2237] surge isolado destes dois grupos (ALVES et al. 2010: 136: Fig. 2). Estas estruturas escavadas no subsolo são formadas por uma antecâmara e uma câmara funerária interligadas entre si, tendo sido atribuída duas referências numéricas a cada hipogeu: a primeira correspondente à unidade estratigráfica da antecâmara, a segunda à da câmara funerária (Fig. 2). A antecâmara serve como espaço de entrada ao sepulcro. A sua morfologia é variável, tendo sido catalogadas cerca de cinco variantes morfológicas em TV3 (Alves et al. 2010: Figura 5) (Fig. 3). Numa das paredes da antecâmara é aberta uma passagem que desce até à câmara funerária (PORFírIo \& SERRA 2010). Esta última tem por sua vez uma forma mais homogénea do que a antecâmara, com paredes curvas e piso plano, assemelha-se em planta a uma forma ovalada. As suas dimensões variam entre $1 \mathrm{~m}$ e $1,5 \mathrm{~m}$ de altura máxima e entre $1,4 \mathrm{~m}$ e $2 \mathrm{~m}$ de comprimento máximo por aproximadamente $1,5 \mathrm{~m}$ de largura máxima.
Em 13 hipogeus de TV3 verificou-se que após a deposição dos indivíduos na câmara funerária, esta foi selada com grandes blocos líticos colocados na vertical e posteriormente revestidos por um composto orgânico constituído por argila escura, compacta e de grão grosseiro, juntamente com cera de abelha e própolis, conforme indicam os resultados das análises realizadas a algumas argilas (FRADE et al. 2014). O sedimento utilizado para estas análises foi recolhido nos hipogeus [1489] [1490] e [1712] - [1713], e até à data a interpretação avançada para a utilização deste composto em contextos funerários está relacionada com as propriedades impermeabilizadoras do mesmo, o que poderá favorecer a preservação tanto do espaço interno do sepulcro como das respectivas inumações (FRADE et al. 2014).

\section{O ESPÓLIO OSTEOLÓGICO HUMANO}

\subsection{Materiais e Métodos}

Nem todos os hipogeus de TV3 forneceram restos ósseos humanos. Do Núcleo 1, composto por 20 hipogeus, os hipogeus [968] - [Destruída], [1395] - [1394] e [697] - [710] não tinham qualquer material osteológico associado, e como tal foram excluídos desta análise. Também não foi
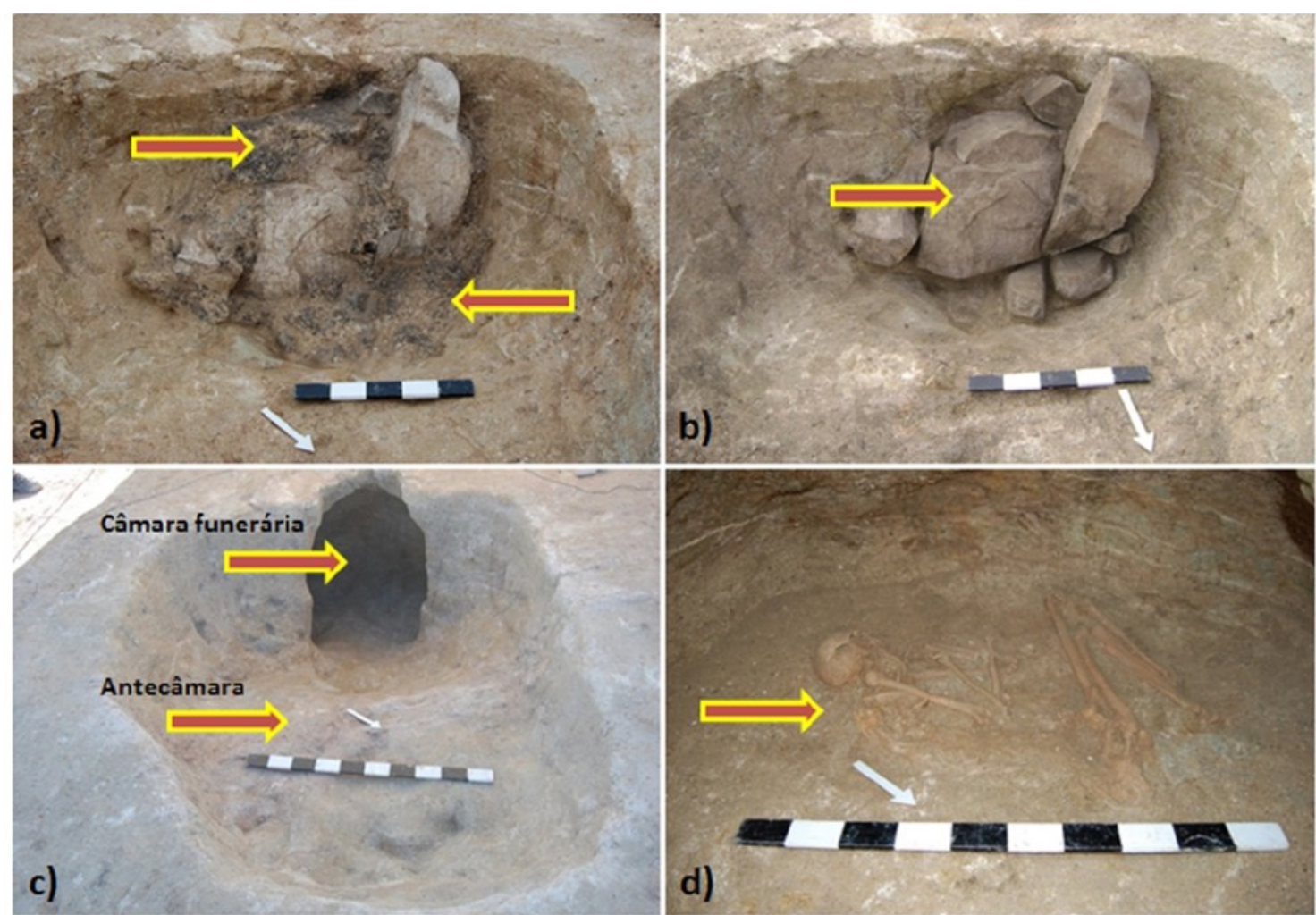

Fig. 2. Hipogeu [1489] - [1490]: a) Câmara funerária selada com lajes de pedra e envolto com um sedimento escuro, composto por argila, cera de abelha e própolis; b) Destaque nas lajes de pedra após remoção do sedimento; c) Câmara funerária aberta, permitindo ver o desnível entre a antecâmara e a câmara funerária; d) Esqueleto [1382] no interior da câmara funerária [1490] (Adaptado de Alves et al. 2009).

Fig. 2. Hypogeum [1489] - [1490]: a) Funerary chamber sealed with slabs filled with black greasy earth, made from clay, beewax and propolis; b) Slabs after the removal of the black greasy earth; c) Funerary chamber now opened, allowing to see disparity between the prechamber and the funerary chamber; d) Skeleton [1382] inside the funerary chamber [1490] (Adapted from ALVES et al. 2009). 


\begin{tabular}{|c|c|c|c|c|c|}
\hline Forma & 1 & 2 & 3 & 4 & 5 \\
\hline Descrição & Quadrangular & Rectangular & Rectangular & Ovalada & Em "Poço" \\
\hline N (25) & 10 & 5 & 4 & 4 & 2 \\
\hline Morfologia & & & & & \\
\hline
\end{tabular}

Fig. 3. Representatividade e planta de cada uma das formas de hipogeu de TV3 (Adaptado de ALVES et al. 2010: 137).

Fig. 3. Representation and plant of each form of Hypogeum in TV3 (Adapted from ALVES et al. 2010: 137).

realizada a análise do contexto funerário [697] [710], uma vez que os elementos osteológicos recuperados, por questões logísticas, não se encontravam presentes aquando da análise laboratorial. Quanto ao Núcleo 2, este é composto por cinco hipogeus cujo espólio osteológico foi estudado, exceptuando-se apenas o hipogeu [573] - [574] do qual não foram recuperados ossos humanos.

Em primeira instância, procedeu-se à limpeza de todo o material osteológico, e só posteriormente se realizou o inventário e análise laboratorial dos esqueletos. De uma forma geral, a análise foi condicionada pelo mau estado de preservação da amostra. O solo ácido, a fauna e o contacto com a água foram alguns dos factores tafonómicos extrínsecos que parecem ter agravado a preservação dos ossos (FERREIRA 2009). Em outros casos, a destruição do espaço sepulcral por acções antrópicas posteriores parece ter sido a principal responsável (FERREIRA 2009).

A análise antropológica dos ossos foi, na maioria dos casos, realizada macroscopicamente. Alguns elementos foram excepção, nomeadamente na observação de alguns caracteres morfológicos dentários e na análise de alguns padrões específicos de desgaste dentário, foi necessário recorrer ao uso de uma lupa. Em outros casos foi ainda necessário recorrer a análises radiológicas tendo sido usado o Mammograph General Electrics, senographe DMR, Voltagem: $30 \mathrm{kV}$; exposição: $63 \mathrm{mAs}$.

Para a diagnose sexual, foram seguidas as recomendações de Ferembach et al. (1980) e Buikstra \& Ubelaker (1994), além dos métodos de Silva (1995), Wasterlain (2000) e Bruzek (2002).

Para a estimativa da idade à morte foram utilizados os métodos de Lovejoy et al. (1985), Brooks \& Suchey (1990) e MacLaughlin (1990) para os adultos. Para os não adultos foram aplicadas as metodologias recomendadas por Schaefer (2009), além dos métodos de Smith (1991) e Alqahtani et al. (2010) para a calcificação dentária.

A metodologia de Martin \& Saller (1957) foi a seleccionada para a estimativa dos índices de achatamento e de robustez, já para a estimativa da estatura foram usados os métodos de Mendonça (2000) e Santos (2002).
No âmbito do estudo morfológico não métrico, a presença de caracteres cranianos foi registada segundo as definições de Saunders (1978) e Hauser \& De Stefano (1989) e para os caracteres póscranianos seguiram-se as recomendações de Finnegan (1978). No estudo dos caracteres morfológicos dentários, foi usado o sistema Arizona State University Dental Anthropology System (ASUDAS) de Turner et al. (1991), segundo as adaptações de Silva (2012). Foi ainda incluída a análise da hipertrofia das raízes dos primeiros incisivos superiores, caractere morfológico recentemente proposto por Cunha et al. (2012). Os resultados obtidos na análise da morfologia dentária foram posteriormente comparados com algumas das amostras populacionais globais descritas em Scott \& Turner (1997: A2), do Neolítico Final/ Calcolítico Peninsular (SILVA 2012; CUNHA 2015) e da Idade do Bronze Peninsular (AL OuMAOUI 2009), recorrendo ao programa SPSS (Versão 21) para a realização da análise de componentes principais a fim de estimar potenciais afinidades biológicas entre as amostras.

$\mathrm{Na}$ análise paleopatológica o estudo de alterações degenerativas articulares seguiu as recomendações de Buikstra \& Ubelaker (1994), levando em consideração as adaptações de Assis (2007:68). Para a análise das alterações das enteses foi usado o método de Mariotii et al. (2004, 2007), e no registo e classificação de espigas laminares na coluna vertebral o de Crubézy (1988).

Já referente à patologia oral, foi usada a metodologia de Moore \& Corbett (1971) para o registo das lesões cariogénicas, e Lukacs (1989) para o grau de severidade das mesmas. Para a classificação das lesões periapicais foi usado o método de Dias e Tayles (1997), e para as patologias periodontais a classificação de Kerr (1988). O tártaro foi classificado segundo Martin \& Saller (1957). O registo das hipoplasias lineares do esmalte foi realizado com base nas recomendações de Steckel et al. (2006) e o desgaste dentário foi classificado segundo a metodologia de Smith (1984) adaptada por Silva (1996). Para o registo das fracturas dentárias seguiram-se as recomendações de Molnar (2008) e para o diagnóstico de hipercementose, Kohli et al. (2011). 


\subsection{Resultados}

A análise antropológica permitiu identificar um total de 28 indivíduos, recuperados de 19 sepulcros individuais, três duplos (uma inumação in situ com uma redução associada) e um triplo (enterramento duplo com uma redução associada) e dois contextos funerários inconclusivos. Todos estes restos ósseos humanos foram recuperados da câmara funerária. Para além destes, um hipogeu continha um enterramento com uma redução asso- ciada na câmara e outra inumação primária na antecâmara. Destes, 22 pertencem a adultos (11 do sexo feminino e nove do masculino), cinco a não adultos, para além de um esqueleto ao qual não foi possível atribuir uma classificação etária. Alguns dados do âmbito da antropologia funerária e os elementos paleodemográficos por hipogeu podem ser consultados na Tabela 2.

Tabela 2 - Os Hipogeus, respectivas inumações, resultados paleodemográficos e espólio votivo (ALVES et al. 2009; Ferreira, 2009). Table 2 - The Hypogea, respective burials, paleodemographic results and funerary offerings (ALVES et al. 2009; Ferreira 2009).

\begin{tabular}{|c|c|c|c|c|c|c|c|}
\hline $\begin{array}{c}\text { Hipogeu } \\
(\mathrm{n}=21)\end{array}$ & $\begin{array}{c}\text { Orientação } \\
\text { (Hipogeu) }\end{array}$ & $\begin{array}{c}\text { Indivíduo } \\
(\mathrm{n}=\mathbf{2 8})\end{array}$ & Deposição & $\begin{array}{r}\text { Orientação } \\
\text { (Indivíduo) }\end{array}$ & Sexo & Idade & Espólio \\
\hline $\begin{array}{c}1086]-[1622] \\
\text { Núcleo } 1 \\
\end{array}$ & $\mathrm{E}-\mathrm{O}$ & {$[1514]$} & $\begin{array}{l}\text { Dec. Lat. } \\
\text { Direito }\end{array}$ & $\mathrm{NE}-\mathrm{SO}$ & M & $\begin{array}{c}\text { Adulto } \\
(>30 \text { anos })\end{array}$ & 1 Oferenda cárnea \\
\hline $\begin{array}{l}{[1157]-[1158]} \\
\quad \text { Núcleo } 1\end{array}$ & SE - NO & {$[1134]$} & $\begin{array}{l}\text { Dec. Lat. } \\
\text { Direito }\end{array}$ & NE - SO & $\mathrm{F}$ & $\begin{array}{c}\text { Adulto } \\
\text { Jovem } \\
(21-24 \mathrm{a}- \\
\text { nos }) \\
\end{array}$ & 1 Taça de carena baixa \\
\hline$[1267]-[1792]$ & SE - NO & [1714] & $\begin{array}{l}\text { Dec. Lat. } \\
\text { Direito }\end{array}$ & $\mathrm{NE}-\mathrm{SO}$ & F & $\begin{array}{c}\text { Adulto } \\
(>25 \text { anos })\end{array}$ & $\begin{array}{l}1 \text { Vaso de corpo oval e bordo vertical: } \\
1 \text { punhal; } 1 \text { punção; } 1 \text { oferenda cárnea }\end{array}$ \\
\hline $\begin{array}{c}{[1284]-[1415]} \\
\text { Núcleo } 1 \\
\end{array}$ & $\mathrm{SO}-\mathrm{NE}$ & {$[1340]$} & $\begin{array}{l}\text { Dec. Lat. } \\
\text { Direito }\end{array}$ & $S-N$ & $\mathrm{~F}$ & $\begin{array}{c}\text { Adulto } \\
(>25 \text { anos })\end{array}$ & 1 Taça em calote esférica; 1 punção \\
\hline $\begin{array}{l}{[1298]-[1695]} \\
\quad \text { Núcleo } 1\end{array}$ & NE - SO & {$[1570]$} & $\begin{array}{l}\text { Dec. Lat. } \\
\text { Direito }\end{array}$ & NO - SE & - & $\begin{array}{c}\text { Adulto } \\
(>25 \text { anos })\end{array}$ & $\begin{array}{l}1 \text { Vaso de corpo esférico e bordo } \\
\text { vertical; } 2 \text { taças em calote esférica; } 1 \\
\text { punção; } 1 \text { punhal; } 1 \text { oferenda cárnea }\end{array}$ \\
\hline $\begin{array}{c}{[1307]-[1370]} \\
\text { Núcleo } 1 \\
\end{array}$ & NO - SE & {$[1363]$} & - & - & Ind. & Ind. & 1 Taça em calote esférica; 1 punção \\
\hline $\begin{array}{c}{[1319]-[1320]} \\
\text { Núcleo } 1 \\
\end{array}$ & $\mathrm{~N}-\mathrm{S}$ & [1169] & - & - & - & Adulto** & 1 Garrafa de cerâmica decorada \\
\hline $\begin{array}{c}{[1489]-[1490]} \\
\text { Núcleo } 1\end{array}$ & $\mathrm{~N}-\mathrm{SO}$ & [1382] & $\begin{array}{l}\text { Dec. Lat. } \\
\text { Esquerdo }\end{array}$ & $\mathrm{SE}-\mathrm{NO}$ & M & $\begin{array}{l}\text { Adulto }(>30 \\
\text { anos) }\end{array}$ & 1 Oferenda cárnea \\
\hline \multirow{3}{*}{$\begin{array}{l}{[1662]-[1664]} \\
\quad \text { Núcleo } 1\end{array}$} & \multirow{3}{*}{$\mathrm{E}-\mathrm{O}$} & {$[1361]$} & $\begin{array}{l}\text { Dec. Lat. } \\
\text { Esquerdo }\end{array}$ & $\mathrm{SE}-\mathrm{NO}$ & M & $\begin{array}{c}\text { Adulto } \\
(>25 \text { anos })\end{array}$ & - \\
\hline & & {$[1534]$} & $\begin{array}{l}\text { Dec. Lat. } \\
\text { Direito }\end{array}$ & NE - SO & - & $\begin{array}{l}\text { Não Adulto } \\
(12-14 \\
\text { anos })\end{array}$ & \multirow{2}{*}{$\begin{array}{l}1 \text { Vaso de forma } 7 \text { argárica; } 1 \text { oferenda } \\
\text { cárnea de ovino * }\end{array}$} \\
\hline & & {$[1532]$} & Redução & - & $\mathrm{F}$ & $\begin{array}{c}\text { Adulto } \\
(>25 \text { anos })\end{array}$ & \\
\hline $\begin{array}{l}{[1712]-[1713]} \\
\text { Núcleo } 1\end{array}$ & $\mathrm{E}-\mathrm{O}$ & {$[1565]$} & $\begin{array}{l}\text { Dec. Lat. } \\
\text { Direito }\end{array}$ & NE - SO & - & $\begin{array}{l}\text { Adolescente } \\
(14-19 \\
\text { anos })\end{array}$ & 1 Jarrinha de cerâmica decorada \\
\hline $\begin{array}{c}{[1769]-[1770]} \\
\text { Núcleo } 1 \\
\end{array}$ & $\mathrm{~S}-\mathrm{N}$ & {$[1575]$} & $\begin{array}{l}\text { Dec. Lat. } \\
\text { Direito }\end{array}$ & NE - SO & $\mathrm{F}$ & $\begin{array}{c}\text { Adulto } \\
(>25 \text { anos })\end{array}$ & 1 Taça forma Atalaia; 1 punção \\
\hline \multirow{2}{*}{$\begin{array}{l}{[1947]-[1948]} \\
\quad \text { Núcleo } 1\end{array}$} & \multirow{2}{*}{ NO - SE } & {$[1781]$} & $\begin{array}{l}\text { Dec. Lat. } \\
\text { Esquerdo }\end{array}$ & $\mathrm{SE}-\mathrm{NO}$ & M & $\begin{array}{l}\text { Adulto } \\
\text { (>25anos) }\end{array}$ & \multirow{2}{*}{1 Punção; 1 oferenda cárnea } \\
\hline & & [1782] & Redução & . & F & $\begin{array}{c}\text { Adulto } \\
(>25 \text { anos })\end{array}$ & \\
\hline $\begin{array}{c}1949]-[1950] \\
\text { Núcleo } 1 \\
\end{array}$ & $\mathrm{O}-\mathrm{E}$ & [1799] & $\begin{array}{l}\text { Dec. Lat. } \\
\text { Direito }\end{array}$ & $\mathrm{E}-\mathrm{O}$ & $\mathrm{F}$ & $\begin{array}{c}\text { Adulto } \\
(>25 \text { anos })\end{array}$ & $\begin{array}{c}1 \text { Vaso fechado com carena alta; } 1 \\
\text { punção; } 1 \text { oferenda cárnea* }\end{array}$ \\
\hline $\begin{array}{c}{[2119]-[2120]} \\
\text { Núcleo } 1 \\
\end{array}$ & $\mathrm{O}-\mathrm{E}$ & {$[2007]$} & $\begin{array}{l}\text { Dec. Lat. } \\
\text { Direito }\end{array}$ & $\mathrm{N}-\mathrm{S}$ & M & $\begin{array}{c}\text { Adulto } \\
(>25 \text { anos })\end{array}$ & 1 Punção; 1 oferenda cárnea* \\
\hline $\begin{array}{l}{[2356]-[2357]} \\
\text { Núcleo } 1\end{array}$ & $\mathrm{NE}-\mathrm{SO}$ & [2051] & $\begin{array}{l}\text { Dec.Lat. } \\
\text { Direito }\end{array}$ & NO - SE & $\mathrm{F}$ & $\begin{array}{c}\text { Adulto } \\
(>25 \text { anos })\end{array}$ & $\begin{array}{l}1 \text { Taça de carena baixa; } 1 \text { punção; } 1 \\
\text { oferenda cárnea }\end{array}$ \\
\hline $\begin{array}{c}{[2417]-[2418]} \\
\quad \text { Núcleo } 1 \\
\end{array}$ & $\mathrm{SO}-\mathrm{NE}$ & {$[2241]$} & $\begin{array}{l}\text { Dec.Lat. } \\
\text { Direito }\end{array}$ & SE - NO & $\mathrm{F}$ & $\begin{array}{c}\text { Adulto } \\
(>30 \text { anos })\end{array}$ & $\begin{array}{l}1 \text { Taça forma Odivelas; } 1 \text { punhal; } 1 \\
\text { possível fragmento de punção }\end{array}$ \\
\hline $\begin{array}{l}{[2215]-[2231]} \\
\text { Núcleo } 2\end{array}$ & SE - NO & [2004] & $\begin{array}{l}\text { Dec. Lat. } \\
\text { Direito }\end{array}$ & SE - NO & - & $\begin{array}{l}\text { Não-Adulto } \\
(6-9 \text { anos })\end{array}$ & $\begin{array}{l}1 \text { Vaso de corpo oval e bordo vertical; } \\
1 \text { punhal; } 1 \text { anel }\end{array}$ \\
\hline \multirow{3}{*}{$\begin{array}{l}{[2471]-[2472]} \\
\quad \text { Núcleo } 2\end{array}$} & \multirow{3}{*}{$\mathrm{SO}-\mathrm{NE}$} & [2367] & $\begin{array}{l}\text { Dec. Lat. } \\
\text { Esquerdo }\end{array}$ & SE -NO & - & $\begin{array}{l}\text { Não Adulto } \\
(7-10 \text { anos })\end{array}$ & \multirow{3}{*}{$\begin{array}{l}1 \text { Vaso de forma } 7 \text { argárica; } 1 \text { falange } \\
\text { decorada }\end{array}$} \\
\hline & & {$[2368]$} & $\begin{array}{l}\text { Dec. Lat. } \\
\text { Esquerdo }\end{array}$ & $\mathrm{SE}-\mathrm{NO}$ & - & $\begin{array}{l}\text { Não Adulto } \\
(7-9 \text { anos })\end{array}$ & \\
\hline & & $\begin{array}{c}{[2365]+} \\
{[2458]} \\
\end{array}$ & Redução & - & M & $\begin{array}{c}\text { Adulto } \\
\text { (>35anos) }\end{array}$ & \\
\hline \multirow{2}{*}{$\begin{array}{l}{[2498]-[2497]} \\
\quad \text { Núcleo } 2\end{array}$} & \multirow{2}{*}{$\mathrm{S}-\mathrm{N}$} & {$[2032]$} & $\begin{array}{c}\text { Decúbito } \\
\text { Dorsal }\end{array}$ & NO - SE & M & $\begin{array}{c}\text { Adulto } \\
(>35 \text { anos })\end{array}$ & \multirow{2}{*}{1 Oferenda cárnea* } \\
\hline & & [2033] & Redução & - & M & $\begin{array}{c}\text { Adulto } \\
(>35 \text { anos })\end{array}$ & \\
\hline \multirow{2}{*}{$\begin{array}{l}{[2550]-[2551]} \\
\quad \text { Núcleo } 2\end{array}$} & \multirow{2}{*}{$\mathrm{SO}-\mathrm{NE}$} & [2069] & $\begin{array}{l}\text { Dec. Lat. } \\
\text { Direito }\end{array}$ & SE - NO & $\mathrm{F}$ & $\begin{array}{c}\text { Adulto } \\
\text { (>35anos) }\end{array}$ & \multirow{2}{*}{$\begin{array}{l}1 \text { Jarra de cerâmica decorada; } 1 \text { colar; } \\
1 \text { punção; } 1 \text { possível oferenda cárnea* }\end{array}$} \\
\hline & & $\begin{array}{c}{[2068]-} \\
{[2000]}\end{array}$ & Redução & - & M & $\begin{array}{c}\text { Adulto } \\
(>25 \text { anos })\end{array}$ & \\
\hline $\begin{array}{l}{[2236]-[2237]} \\
\text { Núcleo } 3 \\
\end{array}$ & $\mathrm{O}-\mathrm{E}$ & [2203] & $\begin{array}{l}\text { Dec.Lat. } \\
\text { Direito }\end{array}$ & $\mathrm{NE}-\mathrm{SO}$ & $\mathrm{F}$ & $\begin{array}{c}\text { Adulto } \\
(>25 \text { anos })\end{array}$ & 1 Taça em calote esférica; 1 punção \\
\hline
\end{tabular}

** Ospólio datado por radiocarbono (ver tabela 1) ** Os ossos recuperados estão muito fragmentados, e correspondem somente a uma ulna e rádio, no entanto, as dimensões destes e a densidade do osso cortical suportam que
se trata de um indivíduo adulto. 
De acordo com o relatório antropológico referente à exumação dos remanescentes osteológicos das campanhas de escavação deste mesmo sítio arqueológico, o processo de decomposição dos corpos ocorreu maioritariamente em espaço aberto, ou seja, os mortos não eram cobertos com qualquer tipo de sedimento quando depositados na câmara funerária (FERREIRA 2009). Estas informações foram confirmadas em laboratório pela análise e interpretação do registo fotográfico de campo proveniente dos relatórios de Alves et al. (2009) e Ferreira (2009). Ainda segundo Ferreira (2009), são excepções os indivíduos [1134], [1340], [1361], [2367] e [2368], cuja decomposição pode ter ocorrido em espaço fechado. Porém a colma- tação dos corpos destas inumações pode não ter sido intencional, mas causada pelo desabamento da câmara funerária que consequentemente subterrou os respectivos indivíduos (FERREIRA 2009).

Através da observação da Figura 4, podemos constatar que a deposição dos indivíduos foi realizada predominantemente de SE-NO e NE-SO. São excepções o adulto do sexo feminino [1340], orientado para S-N; o adulto [1570], o adulto do sexo feminino [2051] e o adulto do sexo masculino [2032], todos estes orientados para NO-SE; o adulto do sexo feminino [1799], orientado para E-O; o adulto do sexo masculino [2007], orientado para N-S. Estes dados encontram-se também expostos por indivíduo na Tabela 2.

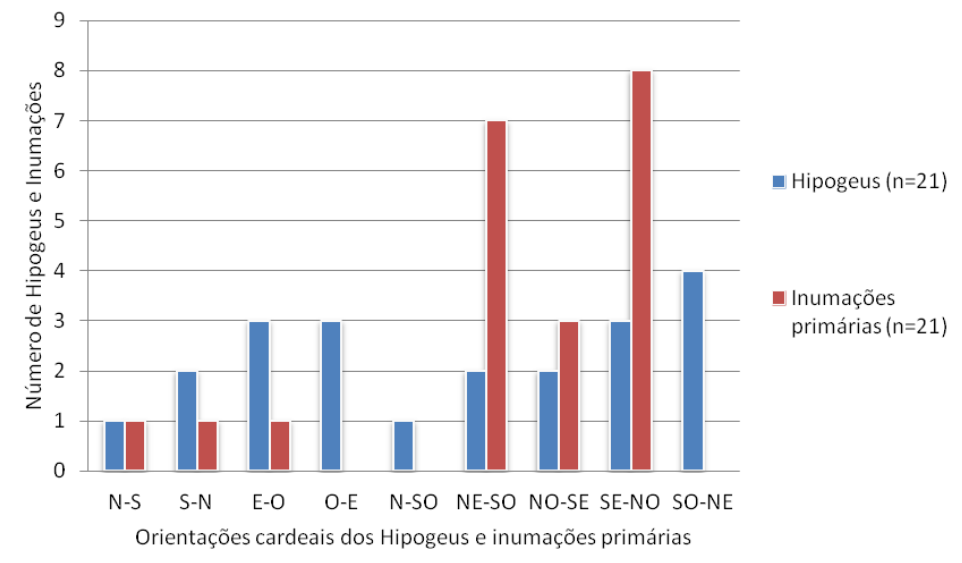

Fig. 4. Orientação das inumações primárias e dos hipogeus de Torre Velha 3.

Fig. 4. Orientation of the primary burials and the Hypogeums from Torre Velha 3.

Na Figura 5, podemos observar a distribuição do espólio votivo atendendo aos dados demográficos. Foram apenas consideradas inumações primárias e individuais, pois, tanto em hipogeus com sinais de reutilização como no caso dos enterramentos duplos poder-se-ia questionar a qual dos indivíduos correspondia o ritual votivo. As dádivas funerárias costumam ser depositadas bastante próximas entre si e são frequentemente encontradas na zona adjacente ao crânio ou à região pélvica dos indivíduos. As oferendas cárneas encontram-se associadas apenas a enterramentos de indivíduos adultos de ambos os sexos. Segundo as análises da Dr. ${ }^{a}$. Marta
Moreno García, correspondem na maioria a membros anteriores (ulna e rádio) esquerdos de animais bovinos (Bovinae), possivelmente de uma espécie doméstica (ALVES et al. 2010) e menos frequentemente de animais ovinos (Ovis/Capra). Quanto aos recipientes cerâmicos e aos punhais, estes parecem estar apenas associados a esqueletos adultos do sexo feminino. Contudo a amostra de punhais é demasiado pequena para realizar inferências mais aprofundadas. Os punções surgem associados a indivíduos do sexo feminino, com excepção do indivíduo adulto do sexo masculino [2007].

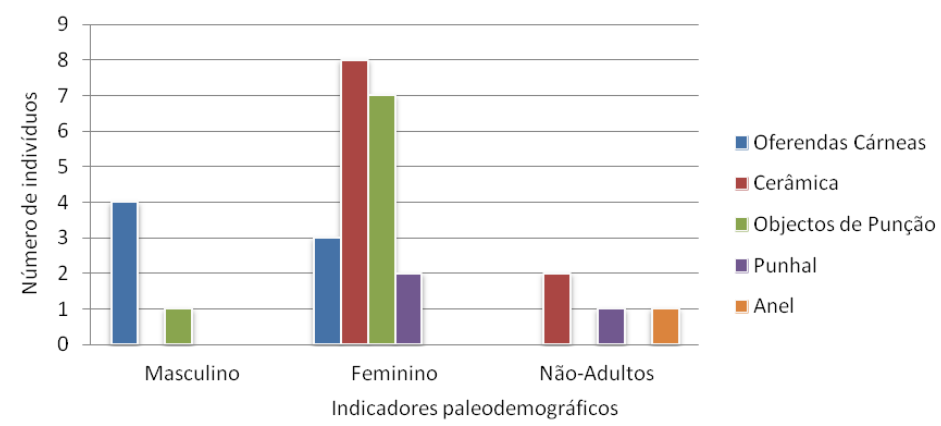

Fig. 5. Espólio votivo em função do sexo estimado para os indivíduos adultos de Torre Velha 3.

Fig. 5. Funerary offering in relation to the estimated sex of the adults in Torre Velha 3. 
No hipogeu [2471] - [2472], orientado para SO - NE, foram exumados os esqueletos [2367], [2368] e [2365] + [2458]. Os dois primeiros compõem uma inumação dupla, a única em toda esta necrópole de hipogeus. Ambos são de não adultos e foram depositados no centro da câmara funerária, orientados para SE - NO em decúbito lateral esquerdo (Figura 6). São também dos poucos esqueletos cuja decomposição se presume ter ocorrido em espaço fechado (FERREIRA 2009). Já o esqueleto [2365] + [2458] pertence a um adulto ( $>$ 30 anos) do sexo masculino. Trata-se de uma redução que nos remete para uma deposição anteriormente realizada neste hipogeu. Este esqueleto, preservando ainda em conexão anatómica os ossos do pé direito [2458], terá sido reduzido parcialmente contra a parede NO da câmara funerária provavelmente para permitir a realização do enterramento duplo anteriormente referido.

Junto a estes foi encontrado um recipiente semelhante à forma 7 argárica (SCHUBART 2004a; 2004b) e uma vértebra caudal de uma espécie animal ainda não identificada ${ }^{1}$. Porém é impossível determinar em que evento estas oferendas foram depositadas, se no momento da deposição dos enterramentos [2365] + [2458], se, posteriormente, no momento de deposição dos esqueletos [2367] e [2368], ou ainda se as oferendas correspondem a um evento distinto.

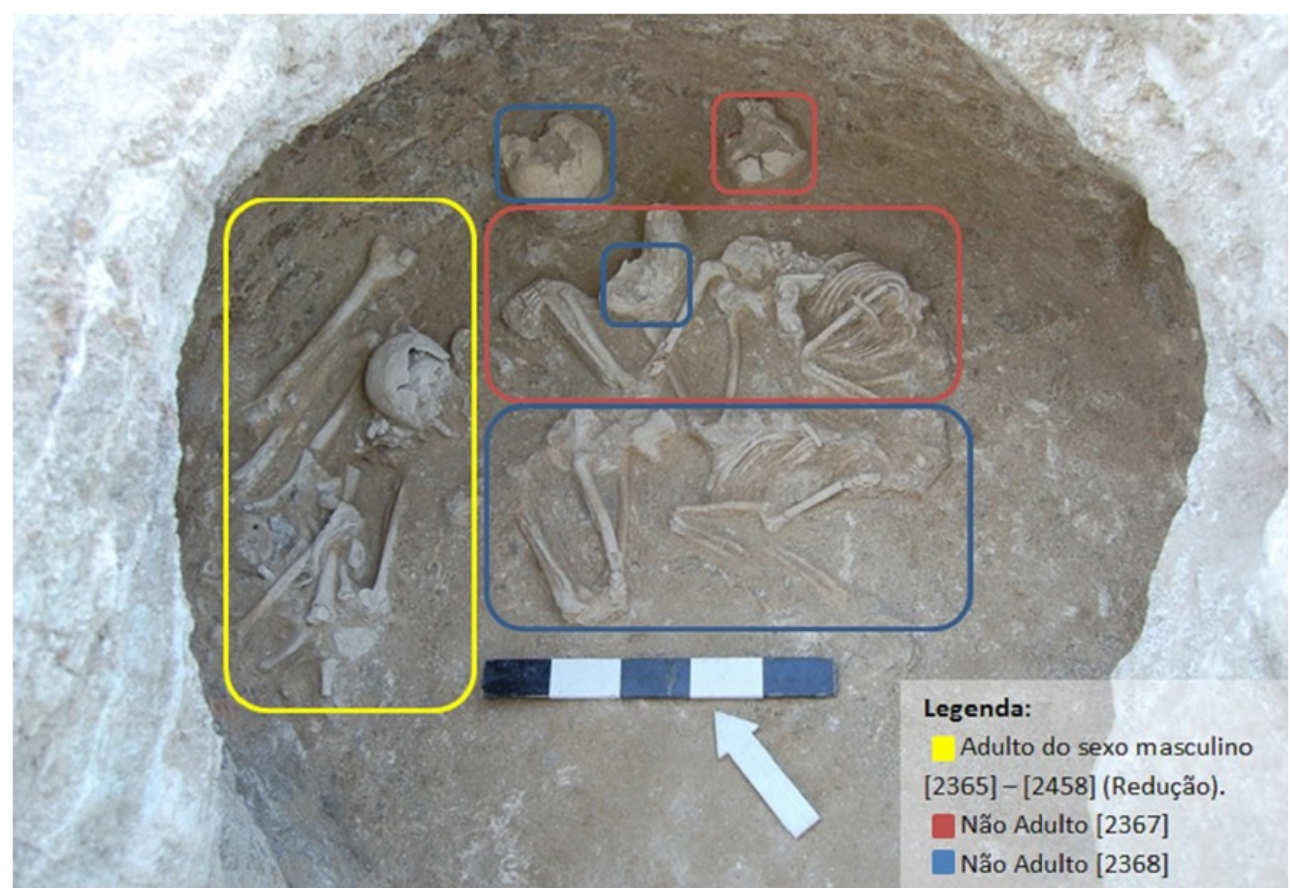

Fig. 6. Câmara funerária do Hipogeu [2471] - [2472] de Torre Velha 3, incluindo o enterramento duplo de 2 não adultos e a redução de um esqueleto adulto do sexo masculino (Adaptado de ALVES et al. 2009; FERREIRA, 2009). Fig. 6. Funerary chamber of the Hypogeum [2471] - [2472] from Torre Velha 3, including the double burial of 2 non adults and the reduction of an adult male skeleton (Adapted from ALVES et al. 2009; FERREIRA, 2009).

Outro caso singular foi identificado no hipogeu [1662] - [1664], onde foram exumados os esqueletos [1361], [1534] e [1532] (Fig. 7). Na câmara funerária [1664] estava depositado em decúbito lateral esquerdo e orientado para $\mathrm{NE}$ - SO o esqueleto [1534] de um não adulto (11-14 anos). Junto ao mesmo foi recuperada uma redução atribuída a um esqueleto [1532] adulto ( $>25$ anos) do sexo feminino que, muito próximo de si, tinha uma taça de tipo Odivelas, um punhal e um punção. O terceiro indivíduo [1361], adulto $(>25$ anos) do sexo masculino foi, inesperadamente, recuperado na antecâmara funerária em decúbito lateral esquerdo e depositado no sentido SE-NO (FERREIRA, 2009).
Desconhece-se a intencionalidade subjacente à escolha deste local para a inumação deste indivíduo, especialmente considerando que a reutilização das câmaras funerárias é frequente, mas não as deposições na antecâmara. Trata-se de uma excepção ao padrão observado neste sítio arqueológico, onde cada hipogeu aparenta ter sido reutilizado uma só vez.

$\mathrm{Na}$ maioria dos casos, não foram identificados indivíduos do mesmo sexo depositados no mesmo hipogeu. A única excepção foi registada para o hipogeu [2498] - [2497], onde foram recuperados dois esqueletos adultos ( $>35$ anos) aparentemente do sexo masculino. 


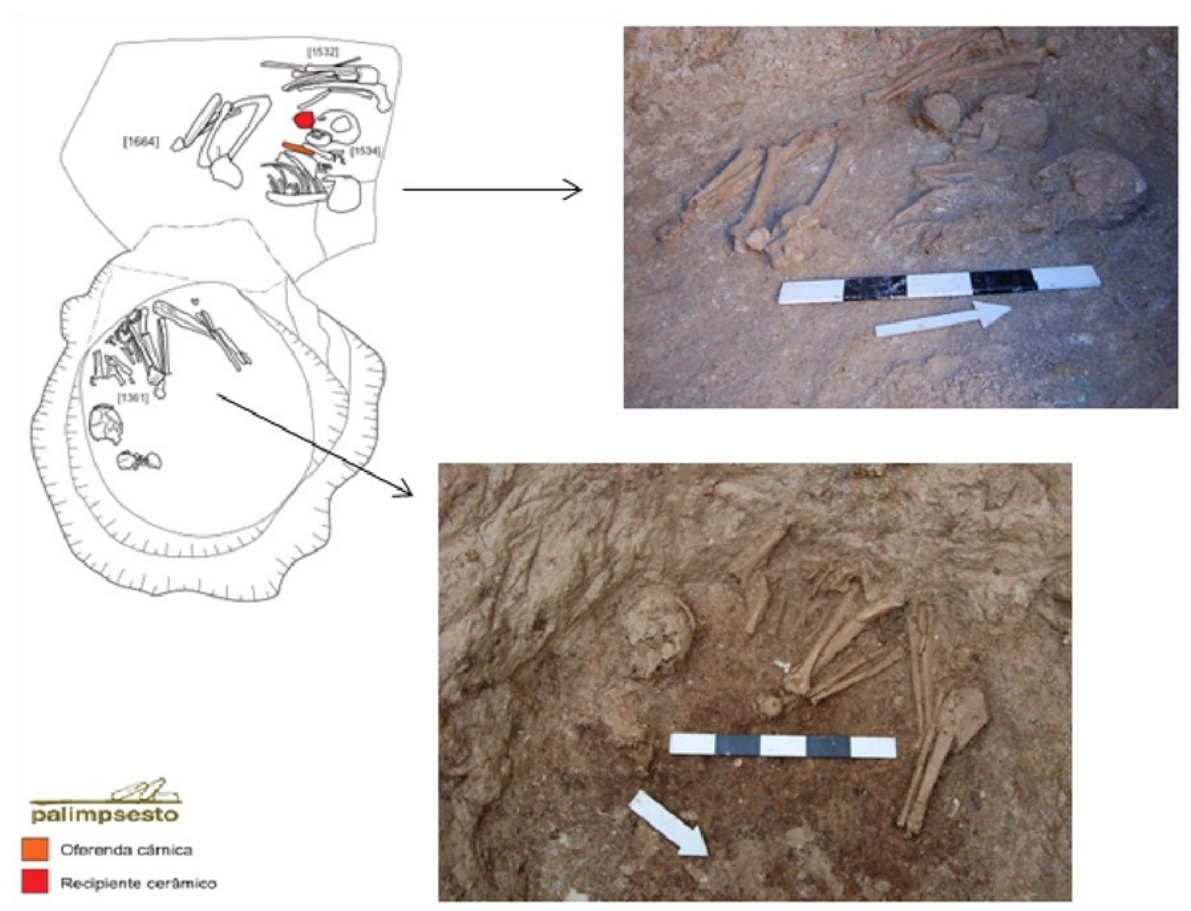

Fig. 7. Hipogeu [1662] - [1664] com um enterramento do indivíduo adulto feminino [1532] e não adulto [1534] sepultados na câmara funerária. Na antecâmara, está presente um enterramento pertencente a um adulto masculino [1361] (Adaptado de Alves et al. 2009; FERREIRA, 2009).

Fig. 7. Hypogeum [1662] - [1664] with the burial of the female adult [1532] and the non adult [1534] in the funerary chamber an the burial of an male adult [1361] in the antechamber (Adapted from ALVES et al. 2009; FERREIRA, 2009).

No que diz respeito aos resultados da análise morfológica métrica (Tabela 3), os resultados dos índices platimétricos e pilástricos, indicam que os adultos de ambos os sexos revelam, em média, valores que atestam o achatamento do fémur. Já relativamente aos valores médios dos índices de achatamento da tíbia, indivíduos do sexo masculino apresentam valores médios de achatamento, enquanto os resultados para o sexo feminino corro- boram a ausência de achatamento neste osso. Relativamente à robustez, dos indivíduos analisados, todos eles revelam robustez do fémur e da tíbia. Já quanto à estimativa da estatura, os valores mais elevados podem ser encontrados associados a esqueletos do sexo masculino, enquanto os indivíduos do sexo feminino apresentam, na maioria, estaturas ligeiramente inferiores.

Tabela 3 - Índices de achatamento e robustez e estimativa da estatura dos esqueletos analisados.

Table 3 - Indices of flattening, robusticity and the estimation of the stature of the analysed skeletons.

\begin{tabular}{|c|c|c|c|c|c|c|c|c|c|c|}
\hline & & \multicolumn{2}{|c|}{ Masculino } & \multirow{2}{*}{ Resultado } & \multicolumn{2}{|c|}{ Feminino } & \multirow{2}{*}{ Resultado } & \multicolumn{2}{|c|}{ Total } & \multirow{2}{*}{ Resultado } \\
\hline & & Média & $\mathbf{N}$ & & Média & $\mathbf{N}$ & & Média & $\mathbf{N}$ & \\
\hline \multirow{3}{*}{ Achatamento } & $\begin{array}{c}\text { Índice Plati- } \\
\text { métrico }\end{array}$ & 79 & 8 & Platimérico & 77,6 & 10 & Platimérico & 78,3 & 18 & Platimérico \\
\hline & $\begin{array}{l}\text { Índice Pilás- } \\
\text { trico }\end{array}$ & 98,3 & 2 & Pilástrico Nulo & 95,1 & 2 & Pilástrico Nulo & 96,7 & 4 & Pilástrico Nulo \\
\hline & $\begin{array}{c}\text { Índice Platic- } \\
\text { némico }\end{array}$ & 62 & 5 & Platicnémico & 69,4 & 7 & Mesocnémico & 65,7 & 12 & Mesocnémico \\
\hline \multirow{2}{*}{ Robustez } & Fémur & 19,9 & 2 & Robusto & 21,5 & 2 & Robusto & 20,7 & 4 & Robusto \\
\hline & Tíbia & 23,8 & 2 & Robusto & 22,2 & 1 & Robusto & 23 & 3 & Robusto \\
\hline \multirow{2}{*}{$\begin{array}{c}\text { Estatura } \\
\text { MENDONÇA } \\
\text { (2000) }\end{array}$} & Fémur & \multicolumn{3}{|c|}{161,69 a $171,01 \pm 6,90 \mathrm{~cm}(\mathrm{n}=3)$} & \multicolumn{3}{|c|}{149,11 a $157,61 \pm 5,92 \mathrm{~cm}(\mathrm{n}=7)$} & \multicolumn{3}{|c|}{-} \\
\hline & Úmero & \multicolumn{3}{|c|}{$165,20 \pm 8,44 \mathrm{~cm}(\mathrm{n}=1)$} & \multicolumn{3}{|c|}{$159,28 \pm 7,7 \mathrm{~cm}(\mathrm{n}=1)$} & \multicolumn{3}{|c|}{-} \\
\hline \multirow{2}{*}{$\begin{array}{c}\text { Estatura } \\
\text { SANTOS (2002) }\end{array}$} & $1^{\circ} \mathrm{MTT}$ & \multicolumn{3}{|c|}{$159,56 \pm 5,35 \mathrm{~cm}(\mathrm{n}=1)$} & \multicolumn{3}{|c|}{$160,96 \pm 5,35 \mathrm{~cm}(\mathrm{n}=1)$} & \multicolumn{3}{|c|}{-} \\
\hline & $2^{\circ} \mathrm{MTT}$ & \multicolumn{3}{|c|}{$170,18 \pm 4,75(=1)$} & \multicolumn{3}{|c|}{-} & \multicolumn{3}{|c|}{-} \\
\hline
\end{tabular}


Outras alterações morfológicas foram analisadas, como nos indivíduos [2007] e [2241], onde foi observada uma morfologia atípica das clavículas que se traduz no seu achatamento ântero-posterior. No indivíduo [2069], adulto ( $>35$ anos) do sexo feminino, observou-se uma morfologia atípica na extremidade proximal do fémur esquerdo: o ângulo do colo femoral é muito baixo, de modo que a cabeça femoral se encontra quase ao mesmo nível do grande trocânter.

Em termos de caracteres morfológicos não métricos, destaca-se a presença da fossa hipotrocânteriana $(33,3 \%, n=6 / 18)$, de ponte mielohióide $(14,3 \%, n=1 / 7)$, de abertura septal $(11,1 \%, n=1 / 9)$, de terceiro trocânter $(8,3 \%, n=1 / 12)$ e ausência da faceta anterior do calcâneo $(16,7 \%, n=1 / 6)$.

No que diz respeito aos resultados da morfologia dentária, não foi identificada a presença de diversos caracteres discretos (ver tabela 4). Já relativamente ao número de raízes: $24 \%(\mathrm{n}=19)$ dos prémolares superiores apresentam duas raízes; $92,9 \%$ $(n=14)$ dos segundos molares superiores apresentam três raízes; $16,7 \%(\mathrm{n}=18)$ dos caninos inferiores apresentam duas raízes; todos os primeiros molares inferiores têm duas raízes $(\mathrm{n}=17)$, assim como os segundos molares inferiores $(\mathrm{n}=21)$. Quanto ao número de cúspides: $14,3 \%(\mathrm{n}=14)$ dos segundos molares inferiores possuem três cúspides; $33,3 \%$ $(n=15)$ dos segundos pré-molares inferiores apresentam duas ou mais cúspides; todos os $1^{\circ}$ molares inferiores apresentam cinco cúspides $(\mathrm{n}=18) ; 90,5 \%$ $(n=21)$ dos segundos molares inferiores têm quatro cúspides. Destes últimos, foi possível observar o padrão de cúspides "Y" em 18,8\% dos casos, e o padrão " $\mathrm{X}$ " em $81,2 \%(\mathrm{n}=16)$. Entre outros caracteres discretos analisados, destaca-se a presença de: Shoveling $(5,9 \%, \mathrm{n}=17)$; Sulcos de interrupção $(20 \%, n=20)$; Crista mesial nos caninos superiores $(5,3 \%, 19 \%)$; Parastyle nos segundos molares superiores $(7,1 \%, n=14)$ e nos terceiros molares superiores $(11,1 \%, n=9)$. Informações mais detalhadas podem ser consultadas na Tabela 4 .

Tabela 4 - Frequências de alguns dos caracteres dentários analisados em Torre Velha 3. Table 4 - Frequencies of some of the dental traits analysed in Torre Velha 3.

\begin{tabular}{|c|c|c|c|c|}
\hline $\begin{array}{l}\text { Caractere } \\
\text { (Por dente) }\end{array}$ & Dente (FDI) & Ponto de cisão & $\mathrm{n}$ & Frequências (\%) \\
\hline Winging & $11 ; 21$ & 1 a 4 & 13 & 0 \\
\hline Shoveling & $11 ; 21$ & 3 a 7 & 17 & 5,9 \\
\hline Double Shoveling & $11 ; 21$ & 2 a 6 & 16 & 0 \\
\hline Sulco de interrupção & $12 ; 22$ & M;D;MD;MED & 20 & 20 \\
\hline Crista Mesial (Canino) & $13 ; 23$ & 1 a 3 & 19 & 5,3 \\
\hline Número de raízes (2) & $14 ; 24$ & 2 & 19 & 26,3 \\
\hline Odontoma & $14 ; 24$ & 1 & 16 & 0 \\
\hline Cúspide de Carabelli & $16 ; 26$ & 5 a 7 & 13 & 0 \\
\hline Cúspide 5 (Metaconule) & $16 ; 26$ & 1 a 5 & 12 & 0 \\
\hline Extensões de Esmalte & $16 ; 26$ & 2 a 3 & 16 & 0 \\
\hline Número de raízes (3) & $17 ; 27$ & 3 & 14 & 92,9 \\
\hline Cúspide de Carabelli & $17 ; 27$ & 5 a 7 & 15 & 0 \\
\hline Parastyle & $17 ; 27$ & 1 a 6 & 14 & $7,1 \%$ \\
\hline Número de cúspides (3) & $17 ; 27$ & 3 & 14 & 14,3 \\
\hline Cúspide 5 (Metaconule) & $17 ; 27$ & 2 a 5 & 12 & 0 \\
\hline Parastyle & $18 ; 28$ & 1 a 6 & 9 & 11,1 \\
\hline Número de raízes & $33 ; 43$ & 2 & 18 & 16,7 \\
\hline Raiz de Tomes & $34 ; 44$ & 4 a 7 & 19 & 0 \\
\hline Número de Cúspides ( $\geq 2$ ) & $35 ; 45$ & $\geq 2$ & 15 & 33,3 \\
\hline Número de Cúspides (4) & $36 ; 46$ & 4 & 18 & 0 \\
\hline Número de Cúspides (5) & $36 ; 46$ & 5 & 18 & 100 \\
\hline Cúspide 6 (Entoconulid) & $36 ; 46$ & 1 a 5 & 16 & 0 \\
\hline Cúspide 7 (Metaconulid) & $36 ; 46$ & 2 a 4 & 16 & 0 \\
\hline Deflecting Wrinkle & $36 ; 46$ & 1 a 3 & 17 & 0 \\
\hline Número de raízes (3) & $36 ; 46$ & 3 & 17 & 0 \\
\hline Crista distal trigonoid & $36 ; 46$ & 1 & 14 & 0 \\
\hline Número de cúspides (4) & $37 ; 47$ & 4 & 21 & 90,5 \\
\hline Cúspide 6 (Entoconulid) & $37 ; 47$ & 1 a 5 & 18 & 0 \\
\hline Cúspide 7 (Metaconulid) & $37 ; 47$ & 2 a 4 & 18 & 0 \\
\hline Padrão de cúspides "Y" & $37 ; 47$ & $\mathrm{Y}$ & 16 & 18,8 \\
\hline Padrão de cúspides " $\mathrm{X}$ " & $37 ; 47$ & $\mathrm{X}$ & 16 & 81,2 \\
\hline Número de raízes (1) & $37 ; 47$ & 1 & 21 & 0 \\
\hline
\end{tabular}


Com o intuito de aprofundar a análise comparativa a um contexto geográfico e cronológico mais próximo, foram ainda selecionadas outras amostras populacionais para serem comparadas, nomeadamente as amostra de El Castellón (Granada, Espanha, Bronze Argárico), Cuesta del Negro (Granada, Espanha, Bronze Argárico), Motilla del Azuer (Daimiel, Espanha, Bronze Manchego) e La Navilla (Arenas del Rey, Espanha, Idade do Bronze) de Al Oumaoui (2009); Cova da Moura (Torres Vedras, Neolítico Final/ Calcolítico), Dólmen da Estrada de Ansião (Coimbra, Neolítico Final), Tholos de Paimogo I (Torres Vedras; Neolítico Final/Calcolítico), hipogeu de São Paulo II (Almada, Neolítico Final/ Calcolítico), hipogeu de Monte de Canelas I (Portimão, Neolítico Final/Calcolítico) (SILVA 2012); Sepulcros 1 e 2 dos Perdigões (Reguengos de Monsaraz, Calcolítico) e Cerro de las Baterías (La Albuera, Espanha, Calcolítico) (CUNHA 2015). Os resultados dos estudos comparativos destacam os seguintes fortes positivos $(>0,5)$ para o componente 1: número de cúspides igual ou superior a dois nos segundos pré-molares inferiores; presença de Entoconulid; presença de Metaconulid; presença de Metaconule. Já o forte negativo em destaque é a presença de cinco cúspides nos primeiros molares inferiores. No componente 2 , os fortes positivos são o número de cúspides dos segundos molares inferiores e o seu padrão de cúspides " $X$ ", e o forte negativo a presença de Cúspides de Carabelli. Por fim, no componente 3 o forte positivo é o número de cúspides igual ou superior a dois nos segundos pré-molares inferiores; o padrão de cúspides "X" dos segundos molares inferiores e a presença de Cúspides de Carabelli. Estas informações atestam por aproximadamente $80,5 \%$ da variação total em análise, e uma vez que o valor de Eigenvalue é superior a um, podemos assumir que o resultado pode ser considerado viável para a análise interpretativa (Tabela 5).

Tabela 5 - Resultados obtidos através da matriz de componentes principais: 3 componentes extraídos. Table 5 - Results obtained through the principal component analyses (PCA): 3 components extracted.

\begin{tabular}{|c|c|c|c|c|}
\hline \multirow{2}{*}{ Dente (FDI) } & \multirow{2}{*}{ Caracteres comparados } & \multicolumn{3}{|c|}{ Componentes } \\
\hline & & 1 & 2 & 3 \\
\hline $35 ; 45$ & Número de Cúspides $(\geq 2)$ &, $\mathbf{5 3 0}$ &,- 339 & ,703 \\
\hline $36 ; 46$ & Número de cúspides (5) &,- 829 &, 174 &, 179 \\
\hline $36 ; 46$ & Cúspide 6 (Entoconulid) &, 859 &, 148 &,- 388 \\
\hline $36 ; 46$ & Cúspide 7 (Metaconulid) & ,759 & ,411 &,- 215 \\
\hline $37 ; 47$ & Número de cúspides &,- 132 &, 816 & ,346 \\
\hline $37 ; 47$ & Padrão de cúspides " $\mathrm{X}$ " & ,088 &, 601 &, 638 \\
\hline $16 ; 26$ & Cúspide de Carabelli & ,328 &,$- \underline{666}$ &, 504 \\
\hline $16 ; 26$ & Cúspide 5 (Metaconule) &, 814 &, 194 &, 118 \\
\hline \multicolumn{2}{|r|}{$\begin{array}{c}\text { Eigenvalue } \\
\text { Variância } \\
\text { Variância Total }\end{array}$} & $\begin{array}{c}3,077 \\
38,458 \\
38,458\end{array}$ & $\begin{array}{r}1,845 \\
23,061 \\
61,520\end{array}$ & $\begin{array}{c}1,517 \\
18,962 \\
80,482\end{array}$ \\
\hline
\end{tabular}

A figura 8 ilustra a variação encontrada através da análise dos componentes 1 (Eixo X) e 2 (Eixo Y). Podemos observar que TV3 encontra-se perto das amostras de São Paulo II e Cova da Moura, que por sua vez estão também próximas das amostras de Motilla del Azuer e Paimogo I. As amostras de Perdigões, El Castellon e La Navilla, apesar de não muito próximas parecem distanciarse ainda mais das restantes, enquanto Cuesta del Negro encontra-se ainda mais isolada.

No âmbito da análise paleopatológica, 63,6\% dos indivíduos (14/22) analisados apresentam sinais de alterações degenerativas articulares, predominando os graus de severidade baixos (entre os graus um e dois descritos em Buikstra \& Ubelaker, $1994)$. Destes, $43 \%$ correspondem ao sexo feminino $(6 / 14), 43 \%$ ao sexo masculino $(6 / 14)$ e o res- tante a adultos de sexo indeterminado (2/14).

Relativamente a alterações da entese, $54,5 \%$ (12/22) dos indivíduos analisados manifestam um ou mais sinais destas alterações, maioritariamente entre os graus um e dois da escala de Mariotti et al. (2004, 2007). Dos afectados, 58\% (7/12) correspondem ao sexo masculino e $42 \%(5 / 12)$ ao sexo feminino.

No indivíduo adulto do sexo masculino [1781] verificou-se um nódulo de Schmorl na norma superior do disco de uma das suas vértebras torácicas. Além disso, foi identificado no navicular direito, mais especificamente na articulação com o astrágalo, evidências de uma antiga lesão necrótica com cerca de $5 \mathrm{~mm}$ de diâmetro.

No esqueleto [2032], adulto ( $>35$ anos) do sexo masculino, foi registada uma lesão unilateral 


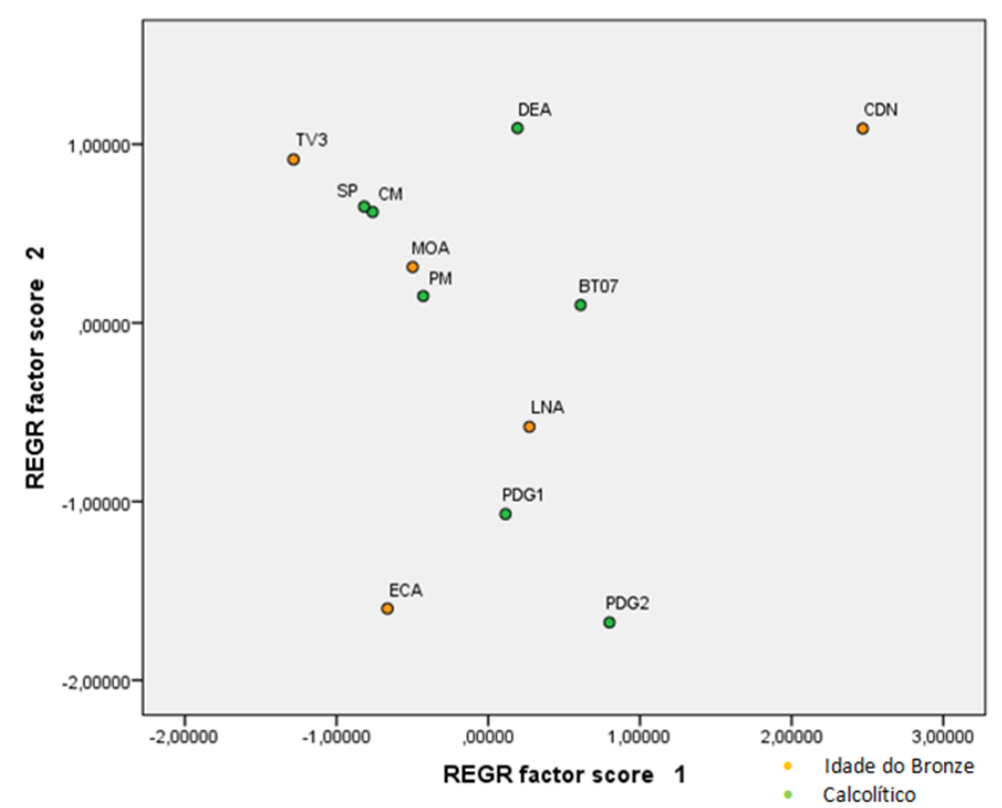

Fig. 8. Gráfico de dispersão dos componentes 1 e 2 retirados dos resultados da análise de componentes principais realizada na amostra de hipogeus de TV3. Legenda: TV3 Torre Velha 3; SP - São Paulo II; CM - Cova da Moura; MOA - Motilla del Azuer; PM - Paimogo I; ECA - El Castellon; DEA - Dólmen da Estrada de Ansião; BT07 - Cerro de las Baterías; LNA - La Navilla; PDG1 - Sepulcro 1 dos Perdigões; PDG2 - Sepulcro 2 dos Perdigões; CDN - Cuesta del Negro.

Fig. 8. Scatter plot of the components 1 and 2 analysed from the results of the principal component analyses made with the Hypogea sample of TV3.

que afecta a região da cabeça femoral direita, com repercussões no respectivo acetábulo do osso coxal (Fig. 9). Macroscopicamente, o fémur apresenta formação óssea exuberante na junção da cabeça com o colo femoral, especialmente nos ângulos anterior e posterior e com aparentes osteófitos nas suas margens. Não se observa a redução da cabeça do fémur. A fovea capitis encontra-se também afectada ainda que não totalmente obliterada, levando a crer que o ligamentum capitis femoris foi de alguma forma preservado. A análise radiológica não revelou qualquer linha de fractura, contudo, estas podem ser reabsorvidas. No osso coxal direito observa-se o alargamento do acetábulo e a formação de osso novo nas suas margens.

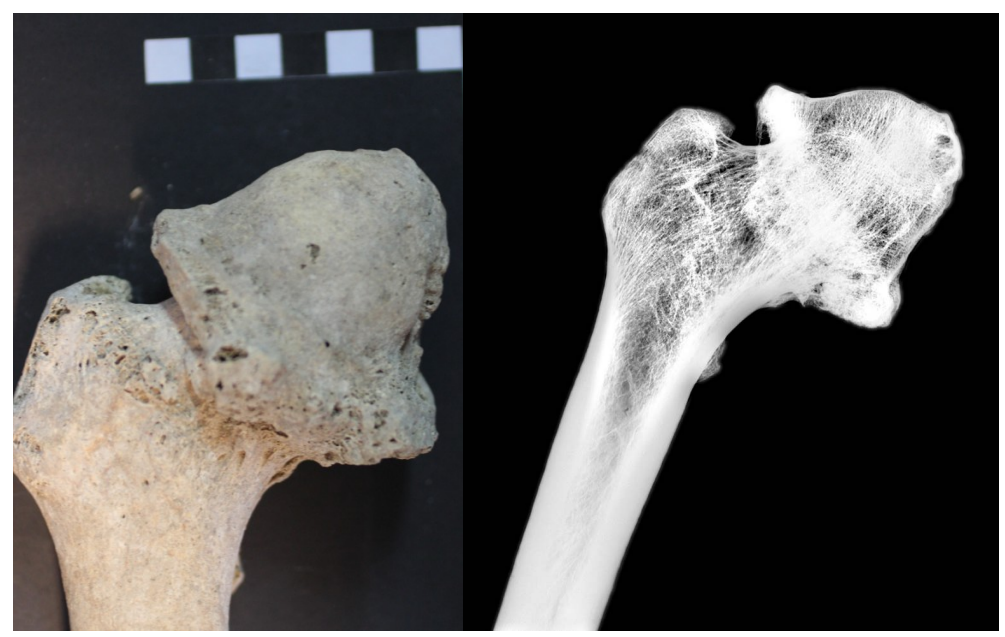

Fig. 9. Alterações degenerativas severas na cabeça e no colo femoral direito do adulto masculino [2032] de TV3. Esquerda: vista anterior; Direita: Exame de raio-X realizado num mamágrafo digital (Mammograph General Electrics, senographe DMR, voltagem: $30 \mathrm{kV}$; exposição: $63 \mathrm{mAs}$ ).

Fig. 9. Severe degenerative alterations in the right femoral head and neck of the male adult [2032] from Torre Velha 3. Left: anterior view; Right: X-ray using a digital mammograph (Mammograph General Electrics, senographe DMR, volts: $30 \mathrm{kV}$; exposition: $63 \mathrm{mAs}$ ). 
No indivíduo adulto ( $>35$ anos) do sexo masculino $[2365]+[2458]$ registaram-se sinais de uma fractura na região distal da ulna direita. Na diáfise do rádio direito foi ainda observado um arqueamento que poderá estar associado ao trauma da ulna (Fig. 10).

No indivíduo adulto ( $>25$ anos) do sexo masculino [2007] observa-se alguma porosidade na região antero-superior da órbita esquerda, o que sugere a presença de cribra orbitalia. No adulto (> 30 anos) do sexo masculino [1514], na superfície cortical exocraniana foi observada, também, alguma porosidade que pode estar relacionada com hiperos- tose porótica, porém a análise é condicionada pela má preservação óssea. Lesões osteolíticas distribuídas de forma irregular nos ossos parietais e no osso occipital foram observadas no indivíduo adulto de sexo desconhecido [1570]. As mesmas estavam mais concentradas na região exocraniana, e foram confirmadas através da análise radiológica. De forma vestigial, também se verificou alguma porosidade na mandíbula, possivelmente relacionada com a mesma condição observada no crânio. Infelizmente, face às fracas condições de preservação do material osteológico, é difícil inferir um diagnóstico mais preciso.

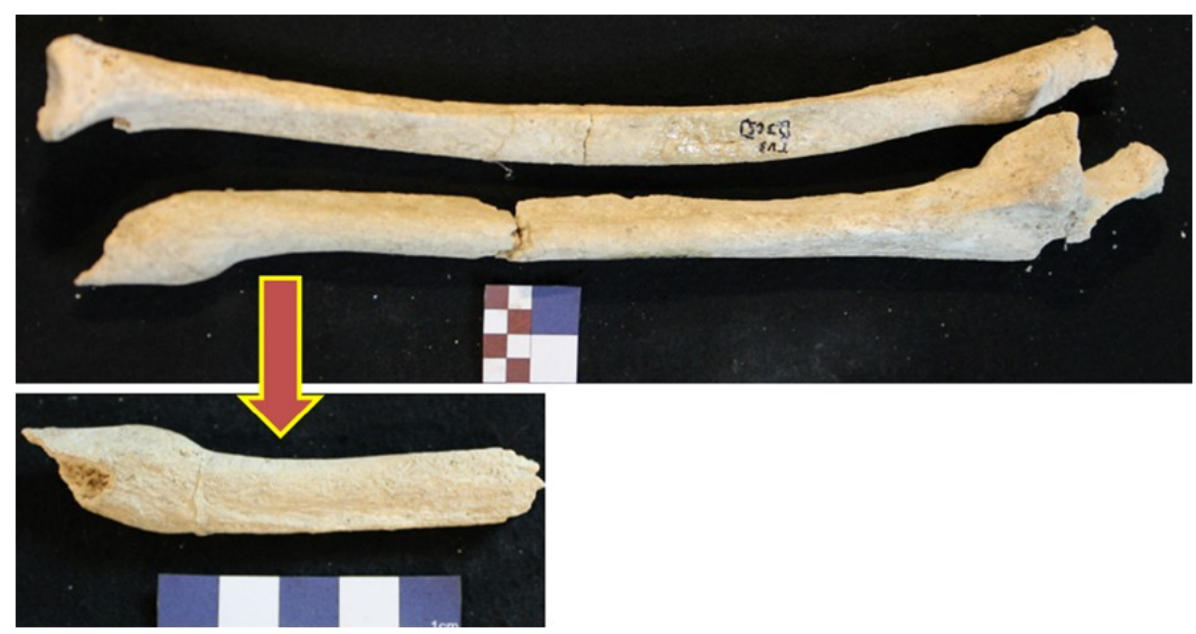

Fig. 10. Fractura da extremidade proximal da ulna direita e curvatura acentuada da diáfise do rádio direito do adulto masculino [2365] de TV3.

Fig. 10. Fracture of the proximal end of the right ulna and bending of the right radius shaft from the adult male [2365] of TV 3.

Quanto à análise da patologia oral, os resultados podem ser consultados mais aprofundadamente na Tabela 6. Seis dos indivíduos destacam-se pelo desgaste dentário atípico, aparentemente causado pelo uso não mastigatório dos dentes, cinco do sexo feminino e um de sexo indeterminado. Estes correspondem a três padrões distintos de desgaste dentário atípico: desgaste severo e inclinado na norma lingual dos molares superiores, e nas normas mesial e distal de molares inferiores $(n=1 / 27$ segundos molares superiores; $n=1 / 33$ - segundos molares inferiores; $n=2 / 23$ - terceiros molares inferiores) (Fig. 11A); desgaste severo em incisivos superiores, inclinado lingualmente, removendo por vezes todo o esmalte ou na forma de polimento com exposição de dentina $(n=3 / 23$, incisivos centrais superiores; $n=1 / 25$ incisivos laterais superiores) (Fig. 11B); num canino superior $(n=1 / 30)$ (Fig. $11 \mathrm{C}$ ) foi observado um sulco linear na norma incisal, orientado mesiodistalmente.

\section{DISCUSSÃO}

Com base nos dados obtidos podemos inferir uma série de características dos contextos funerários realizados em hipogeus do Bronze Pleno de
TV3. Primeiro, parece haver uma forte tendência para as inumações primárias serem realizadas em decúbito lateral $(95,2 \%, n=20 / 21)$ - sendo que destas predominam as inumações em decúbito lateral direito $(71,4 \%, n=15 / 21)$ sobre o esquerdo $(23,8 \%$, $\mathrm{n}=5 / 21$ ). No sexo masculino a posição de inumação é variável, tendo sido registados três casos sobre o lado esquerdo e um sobre o lado direito. Todos os indivíduos do sexo feminino foram inumados em decúbito lateral direito. Nos não adultos, os únicos inumados em decúbito lateral esquerdo foram os esqueletos [2457] e [2458], os restantes não adultos, nomeadamente os esqueletos [1534], [1565] e [2004] foram inumados em decúbito lateral direito. Não parece existir uma relação aparente entre a orientação dos não adultos e a sua idade, uma vez que os indivíduos inumados em decúbito lateral esquerdo têm uma idade à morte estimada entre os cinco e dez anos. Por sua vez, o indivíduo [2004] teria entre seis e nove anos, contudo encontra-se inumado em decúbito lateral direito.

Apenas a deposição do esqueleto do adulto masculino [2032] no hipogeu [2498] - [2497] foi realizada em decúbito dorsal $(4,8 \%, n=1 / 21)$, possivelmente devido à constrição do espaço da câma- 
Tabela 6 - Desgaste dentário, alterações e patologias dentárias observadas na amostra de Torre Velha 3. Table 6 - Dental wear, dental pathologies and alterations observed in the Torre Velha 3 sample.

\begin{tabular}{|c|c|c|c|c|c|c|c|c|c|c|c|c|c|c|c|}
\hline & \multirow[t]{2}{*}{$\begin{array}{c}\text { Dentes } \\
\text { Recuperados }\end{array}$} & \multirow[t]{2}{*}{$\begin{array}{c}\text { Desgaste } \\
\text { (Smith, 1984) }\end{array}$} & \multicolumn{2}{|c|}{ Tártaro } & \multicolumn{2}{|c|}{$\begin{array}{c}\text { Lesões } \\
\text { Cariogénicas }\end{array}$} & \multicolumn{2}{|c|}{ Chipping } & \multicolumn{2}{|c|}{$\begin{array}{c}\text { Lesões } \\
\text { periapicais }\end{array}$} & \multicolumn{2}{|c|}{ Hipercementose } & \multicolumn{3}{|c|}{$\begin{array}{c}\text { Perda dentária } \\
\text { antemortem }\end{array}$} \\
\hline & & & $\mathrm{n}$ & $\%$ & $\mathrm{n}$ & $\%$ & $\mathrm{n}$ & $\%$ & $\mathrm{~N}$ & $\%$ & $\mathrm{~N}$ & $\%$ & $\mathrm{n}$ & $\mathrm{T}$ & $\%$ \\
\hline [2241] & 24 & 3,28 & 0 & 0 & 1 & 4,2 & 0 & 0 & 0 & 0 & 0 & 0 & 1 & 25 & 4 \\
\hline$[2051]$ & 20 & $4,8^{*}$ & 7 & 31,8 & 7 & 35 & 0 & 0 & 2 & 10 & 0 & 0 & 2 & 22 & 9,1 \\
\hline [2203] & 23 & $1,4^{*}$ & 3 & $9 \%$ & 0 & 0 & 0 & 0 & 0 & 0 & 0 & 0 & 0 & 23 & 0 \\
\hline [2007] & 17 & 6,27 & 0 & 0 & 1 & 5,9 & 0 & 0 & 1 & 5,9 & 0 & 0 & 6 & 23 & 26 \\
\hline [1799] & 13 & $5,6^{*}$ & 0 & 0 & 0 & 0 & 0 & 0 & 0 & 0 & 3 & 20 & 2 & 15 & 13 \\
\hline$[1575]$ & 12 & $5,8^{*}$ & 0 & 0 & 3 & 12 & 0 & 0 & 0 & 0 & 0 & 0 & 4 & 16 & 29 \\
\hline [1169] & - & - & - & - & - & - & - & - & - & - & - & - & - & - & - \\
\hline [2004] & $\begin{array}{l}21(\mathrm{P}) \\
11(\mathrm{D})\end{array}$ & $\begin{array}{c}1(\mathrm{P}) \\
1,36(\mathrm{D})\end{array}$ & 0 & 0 & $\begin{array}{c}2 \\
\text { (D) }\end{array}$ & 18,2 (D) & 0 & 0 & 0 & 0 & 0 & 0 & - & - & - \\
\hline [1781] & 23 & 4,65 & 6 & 26 & 2 & 8,7 & 0 & 0 & 0 & 0 & 0 & 0 & 1 & 24 & 4,1 \\
\hline [1782] & 20 & 2,72 & 2 & 10 & 0 & & 0 & 0 & 0 & 0 & 0 & 0 & 0 & 20 & 0 \\
\hline$[1565]$ & - & - & - & - & - & - & - & - & - & - & - & - & - & - & - \\
\hline [1382] & 19 & 5,32 & 1 & 5,3 & 3 & 15,8 & 0 & 0 & 0 & 0 & 0 & 0 & 0 & 19 & 0 \\
\hline [1363] & - & - & - & - & - & - & - & - & - & - & - & - & - & - & - \\
\hline$[1570]$ & 21 & $5,62 *$ & 2 & 9,5 & 4 & 19,1 & 0 & 0 & 0 & 0 & 0 & 0 & 0 & 21 & 0 \\
\hline$[1340]$ & 30 & 1,40 & 7 & 23,3 & 2 & 6,7 & 0 & 0 & 0 & 0 & 0 & 0 & 0 & 30 & 0 \\
\hline [1714] & 21 & $4,71^{*}$ & 1 & 4,8 & 0 & 0 & 0 & 0 & 0 & 0 & 0 & 0 & 1 & 22 & 4,5 \\
\hline [1134] & 32 & 2,81 & 0 & 0 & 0 & 0 & 3 & 9,7 & 0 & 0 & 0 & 0 & 0 & 32 & 0 \\
\hline [1514] & 10 & 5,9 & 0 & 0 & 1 & 10 & 0 & 0 & 0 & 0 & 1 & 10 & 3 & 13 & 23 \\
\hline$[1361]$ & 24 & 3,46 & 0 & 0 & 0 & 0 & 0 & 0 & 0 & 0 & 0 & 0 & 0 & 24 & 0 \\
\hline [1534] & 24 & - & 0 & 0 & 0 & 0 & 0 & 0 & 0 & 0 & 0 & 0 & 0 & 24 & 0 \\
\hline [1532] & 28 & 2,81 & 0 & 0 & 0 & 0 & 0 & 0 & 0 & 0 & 1 & 3,57 & 0 & 28 & 0 \\
\hline [2367] & $\begin{array}{l}11(\mathrm{P}) \\
4(\mathrm{D})\end{array}$ & - & 0 & 0 & 0 & 0 & 0 & 0 & 0 & 0 & 0 & 0 & - & - & - \\
\hline [2368] & $\begin{array}{l}27(\mathrm{P}) \\
11(\mathrm{D})\end{array}$ & - & 0 & 0 & 0 & 0 & 0 & 0 & 0 & 0 & 0 & 0 & - & - & - \\
\hline $\begin{array}{c}{[2365]+} \\
{[2458]}\end{array}$ & 24 & 2,2 & 7 & 29,2 & 1 & 4,2 & 0 & 0 & 0 & 0 & 1 & 4,16 & 0 & 24 & 0 \\
\hline [2069] & 32 & 3,16 & 2 & 6,3 & 1 & 3,1 & 0 & 0 & 0 & 0 & 0 & 0 & 0 & 32 & 0 \\
\hline $\begin{array}{c}{[2068]-} \\
{[2000]}\end{array}$ & 27 & 1,96 & 0 & 0 & 0 & 0 & 0 & 0 & 0 & 0 & 0 & 0 & 0 & 27 & 0 \\
\hline [2032] & 25 & 3,12 & 2 & 8 & 3 & 12 & 0 & 0 & 1 & 4 & 0 & 0 & 1 & 26 & 3,8 \\
\hline [2033] & 28 & 2,28 & 3 & 10,7 & 0 & 0 & 0 & 0 & 0 & 0 & 0 & 0 & 1 & 29 & 3,4 \\
\hline
\end{tabular}

*Indivíduos cujo desgaste dentário é atípico; D - Dentição Decídua; P - Dentição Permanente 


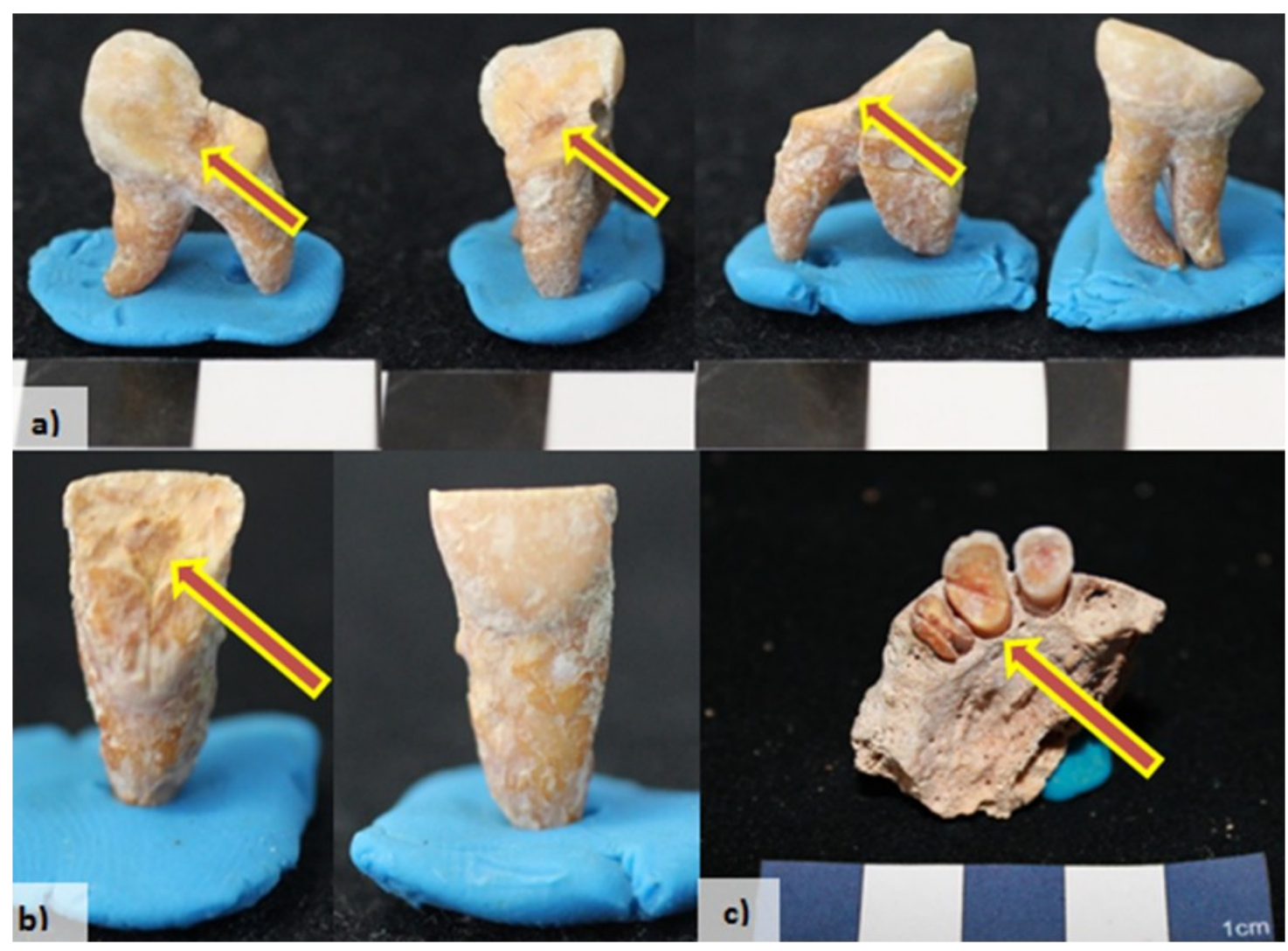

Fig. 11. a) Desgaste severo e inclinado lingualmente do $2^{\circ}$ molar superior direito do indivíduo [2051] adulto do sexo feminino, vista distal, lingual, mesial e bucal respectivamente. b) desgaste inclinado lingualmente no incisivo central superior direito do indivíduo [1570] adulto do sexo feminino. c) Sulco incisal na direcção mesiodistal no dente canino superior direito, desgaste máximo no dente $1^{\circ}$ molar superior direito e desgaste inclinado lingualmente no dente incisivo lateral superior direito do indivíduo [1799] adulto do sexo feminino.

Fig. 11. a) Severe dental wear in the lingual view of the $2^{\text {nd }}$ right superior molar from the female adult [2051]. B) Severe dental wear in the lingual view of the right upper central incisive from the female adult $[1570\}$. c) Mesiodistal incisal groove in the right upper canine, severe dental wear in the $1^{\text {st }}$ right upper molar and severe dental wear in the lingual view of the right lateral upper incisive from the adult female [1799].

ra funerária, já delimitada anteriormente por conta da deposição do indivíduo [2033].

Em todos os hipogeus com sinais de reutilização analisados $(23,8 \%, n=5 / 21)$ o número destas nunca ultrapassou um indivíduo por câmara funerária. Tal sugere que na maioria dos casos a reutilização de hipogeus seria restrita apenas a um segundo episódio de deposição, e possivelmente o hiatus entre os dois eventos seria considerável, tendo em conta a ausência de conexões anatómicas nas reduções, o que indicia que a decomposição da primeira inumação estaria já num estado avançado quando ocorreu a reutilização do espaço funerário. Além disso, o NMI mais alto registado numa câmara funerária foi de 3 indivíduos, uma redução seguida de um enterramento duplo de dois não adultos, no hipogeu [2471] - [2472]. Em Montinhos 6, os dados apontam para uma configuração distinta de TV3, com 9 das 17 câmaras funerárias apresentando inumações individuais e as restantes oito albergando entre dois e/a cinco indivíduos (COSTA \& BAPTISTA 2014). Já o número de enterramentos secundários nesta necrópole chega aos 12 indiví- duos, todos eles adultos. Nos hipogeus de TV3, concluiu-se que todos os enterramentos são primários, mas com reutilização dos espaços funerários. Em Montinhos 6, caso se confirmem as inumações secundárias, podemos estar perante práticas rituais distintas entre comunidades humanas coevas que utilizam arquitecturas funerárias muito semelhantes. Tais variações dos aspectos rituais entre estes dois sítios arqueológicos podem dever-se, por exemplo, a diferenças particulares a certas regiões, assimilando cada região as suas próprias tradições originais, como resultado da desigualdade das dinâmicas evolutivas da própria estrutura de cada grupo (GOMES 1994: 136). Não obstante, ainda não se tem conhecimento de um estudo antropológico aprofundado da necrópole de Montinhos 6, pelo que estas premissas devem ser tomadas com cautela até à publicação de dados mais conclusivos.

Pelo exposto, apesar de existir uma grande heterogeneidade nas orientações dos enterramentos, as variantes NE-SO e SE-NO são as mais recorrentes. No sítio arqueológico de Torre Velha 12, os dados preliminares parecem mostrar algumas seme- 
lhanças com TV3, com um adulto masculino do hipogeu da sondagem 10 orientado para SE - NO e um adulto feminino no hipogeu da sondagem 9 orientado para NE - SO (GOMES et al. 2013).

Mais complexa é a avaliação das orientações dos hipogeus, cuja heterogeneidade é demasiado elevada para realizar quaisquer inferências válidas. Apenas no hipogeu [1947] - [1948] a orientação do sepulcro é idêntica à da inumação depositada no seu interior, neste caso, tanto o hipogeu como o indivíduo [2004] estão orientados para SE - NO.

Relativamente à decomposição dos corpos a opção em espaço aberto parece corresponder ao tipo predominante neste conjunto de hipogeus do Bronze Pleno, tal como em Montinhos 6, onde a antecâmara funerária também parece ter sido coberta quase imediatamente após a realização do último enterramento, e onde o enchimento da câmara funerária parece corresponder sempre ao colapso do tecto da estrutura por causas não antrópicas (FERREIRA 2009; COSTA \& BAPTISTA 2014:36).

A possível manipulação de ossos humanos pode ser sugerida para o hipogeu [2471] - [2472]. Os crânios dos não adultos [2367] e [2368] encontram-se próximos da parede NE da antecâmara funerária, completamente desarticulados do respectivo esqueleto, como se pode observar na Figura 6. Este contexto foi pouco afectado por acções antrópicas posteriores, o que levanta a possibilidade de uma manipulação intencional post mortem, uma vez que a mandíbula do esqueleto [2368] surge igualmente desarticulada do crânio, a aproximadamente metade da distância entre o crânio e o esqueleto. É ainda relevante destacar que a análise morfológica dentária destes dois não adultos revela que ambos possuem cúspides de Carabelli nos molares superiores (ainda que de expressão negativa). Tais caracteres estão fortemente relacionados com factores genéticos, e podem ser usados para inferir e argumentar possíveis afinidades biológicas.

Práticas de manipulação intencional de ossos humanos, especialmente de crânios, parecem frequentes nas práticas rituais do Bronze do Sudoeste. Outros exemplos foram já documentados, como na sepultura de Belmeque onde foram recolhidos os ossos correspondentes a dois indivíduos adultos, sem estarem presentes os respectivos crânios (SOARES 1994; SOARES et al. 2009). Em Cadavais, por sua vez, um dos crânios de uma inumação dupla foi substituído por um vaso de forma globular (ToMÉ et al. 2014:861). Em suma, estas evidências parecem não representar actos isolados, mas sim uma prática mais ampla por parte das comunidades do Sudoeste ao longo da Idade do Bronze. De forma bastante sumária, outros casos podem ser mencionados a partir dos registos de cistas em território português como, por exemplo, nas necrópoles de Alcaria do Pocinho e Curral da Pedra em Castro Marim, na cista n. ${ }^{\circ} 19$ da necrópole de Alcaria, em Monchique, na necrópole da Quitéria,
Sines, ou mais recentemente no sítio Horta do Albardão 3, Évora (PORFÍRIO \& SERRA 2010, com indicação bibliográfica). Em fossas, o registo de rituais semelhantes pode ser encontrado na Fossa 62 de Monte de Cabida 3, onde foi identificado um indivíduo sem crânio (FERREIRA 2014), e ainda possivelmente na necrópole do Casarão da Mesquita 4 , onde foi identificado um indivíduo juvenil cujo crânio apresenta indícios de ter sido manipulado após a decomposição dos tecidos moles (FERREIRA 2014: 245; NUNES et al. 2007: Figura 3).

A cultura material ligada a actividades quotidianas está muitas vezes presente no registo funerário arqueológico, contudo a sua dimensão simbólica permanece ainda por explorar na sua totalidade (ARANDA JIMÉMEZ et al. 2009:140). As oferendas podem ser usadas para interpretar tanto o carácter doméstico como o estatuto social de um indivíduo, mas em alguns casos são também importantes indicadores de outros elementos como a faixa etária, sexo, ocupação ou função dentro de um determinado grupo social (GOMES 1994:131). Neste sentido, a emergência dos estudos antropológicos em necrópoles do Bronze do Sudoeste, em sincronia com a análise dos contextos arqueológicos e a sua cultura material, tem vindo a permitir repensar o estado da arte das práticas mortuárias e o que se pensava das diferenças sociais e laborais entre estas comunidades.

Aqui, o primeiro ponto de análise passa pelas oferendas cárneas que, frequentemente, se consideram associadas a rituais de comensalidade integrados no cerimonial funerário destas comunidades (ARANDA JiMÉNEZ \& ESQUIVEL GUERRERO 2006; SOARES et al. 2009; PORFÍRIO \& SERRA 2010). Estas foram registadas em enterramentos individuais de adultos de ambos os sexos, não estando presentes em enterramentos individuais de não adultos. Nos hipogeus de Torre Velha 12 as oferendas cárneas também correspondem a restos osteológicos de bovídeos e estão presentes em enterramentos primários de adultos de ambos os sexos. Semelhante a TV3, são também o rádio e o cúbito, em conexão anatómica, que compõem as oferendas, e no caso de Torre Velha 12 parecem surgir frequentemente associadas com outros tipos de dádivas funerárias como recipientes cerâmicos de corpo esférico, punhais com rebites em liga de cobre e até mesmo argolas em liga de cobre (GOMES et al. 2013: 725). Seria pertinente, após a publicação dos dados bioantropológicos de Torre Velha 12, realizar um estudo comparativo da relação entre os tipos de dádivas funerárias e o perfil demográfico dos esqueletos.

Também nos hipogeus de Montinhos 6 se destaca a presença de ossos de bovídeos como oferendas cárneas, mas desta vez com a inclusão de oferendas de restos ósseos de ovinos (Ovis/Capra), composto por membros dianteiros direitos (COSTA \& BAPTISTA 2014). Existe, assim, uma tendência para a padronização nas oferendas cárneas de TV3, 
onde aparentemente predominam as peças osteológicas correspondentes aos membros dianteiros esquerdos de uma espécie de bovídeo. Quanto às oferendas de ovino, em TV3 apenas foi registado um único caso no hipogeu [1662] - [1664], aparentemente associada ao não adulto [1534], mas que, dada a presença da redução [1532] no mesmo contexto, esta hipótese deve ser interpretada com cautela. Não obstante, mantem-se a preferência pela parte distal do membro dianteiro (ALVES et al. 2010). Além destes contextos destacados, outros espaços funerários do Bronze Pleno comportam oferendas cárneas como Belmeque (SOARES, 1994), e Outeiro Alto 2 (VALERA \& Filipe 2010; FiliPE et al. 2013).

Relativamente aos recipientes cerâmicos, e no que se refere exclusivamente às inumações individuais, aqueles estão frequentemente associados a enterramentos do sexo feminino. As cerâmicas costumam ser depositadas próximas do crânio ou da região pélvica dos indivíduos. Mais frequentemente encontram-se à frente do crânio, contudo, em casos como o do esqueleto [2051] a oferenda foi depositada nas costas do indivíduo. Nos esqueletos [2203] e [1134] as cerâmicas foram depositadas à frente dos indivíduos e próximas da região pélvica, já no que respeita ao enterramento [1575] o recipiente cerâmico foi depositado próximo da mesma região, mas nas costas do esqueleto.

Os punções foram também maioritariamente identificados em associação com indivíduos femininos, com a excepção do indivíduo masculino [2007], e nunca estão presentes em contextos funerários de não adultos. Quanto aos punhais, estes aparecem novamente associados apenas ao sexo feminino, com a excepção do não adulto [2004] cujo sexo é desconhecido. Os únicos elementos relacionados com o adorno do corpo são um anel recuperado junto ao indivíduo não adulto [2004], um colar com pares de contas de vários materiais recolhido junto aos enterramentos do hipogeu [2550] - [2551], não sendo possível determinar a qual dos indivíduos estaria associado, e por último, um colar de búzios identificado no hipogeu [697] [710], que não faz parte da análise deste texto por não ter sido possível, até ao momento, estudar o respectivo espólio ósseo humano.

No que diz respeito aos dados morfológicos dos indivíduos inumados nos hipogeus de TV3, a estimativa da estatura revela uma diferença de, aproximadamente, $10-11 \mathrm{~cm}$ entre os sexos, um valor enquadrado no dimorfismo sexual humano da estatura. Com excepção do índice de platicnemia (tíbia), os valores médios estimados dos índices morfométricos indicam a presença de achatamento e robustez dos membros inferiores para os indivíduos de ambos os sexos. Tal pode significar que durante $o$ seu quotidiano, tanto homens como mulheres estariam sujeitos a esforços biomecânicos constantes, possivelmente relacionados com tarefas que exigissem uma mobilidade considerável e frequente.
Foram procuradas possíveis justificações para a morfologia atípica das clavículas observada no adulto masculino [2007] e no adulto feminino [2241]. Entre as presumíveis hipóteses, estão acções biomecânicas repetitivas (movimentos recorrentes e semelhantes), possivelmente relacionadas com algumas actividades que incluam um esforço contínuo. Contudo, a hipótese de uma variação anatómica não pode ser excluída. Curiosamente, a mesma morfologia atípica foi observada em esqueletos recuperados de fossas coevas dos sítios de Monte do Vale do Ouro 2 e Ribeira de S. Domingos 1 (PEREIRA 2014), geograficamente próximos de TV3.

Já relativamente à morfologia dentária destes indivíduos, quando comparada com os resultados das amostras populacionais globais recolhidas por Scott \& Turner (1997) expõe não só semelhanças morfológicas dentárias com o Norte de África, mas também com o Oeste e com o Norte Europeu (FIDALGO 2014: 110). Em comparação com outras amostras da Pré-História Peninsular, apesar do número reduzido de carateres analisados, os resultados sugerem uma maior afinidade biológica de TV3 com os indivíduos exumados do hipogeu de São Paulo II e da gruta natural de Cova da Moura, ambas datadas do Neolítico Final/Calcolítico e localizadas na região atlântica. Apenas com base nos presentes dados, parece existir uma maior afinidade biológica entre TV3 e as populações do Calcolítico da Estremadura do que com comunidades geograficamente mais próximas, como seja o sítio arqueológico dos Perdigões, no Alentejo Central. No entanto, um estudo mais aprofundado levado a cabo por Cunha (2015) revela que estas diferenças são mínimas, e podem ser justificadas por mudanças genéticas ou de carácter social ocorridas ao longo deste período temporal, uma vez que esta foi justamente uma fase onde parecem evidenciarse a existência de contactos inter-regionais e a expansão do aproveitamento agro-pastoril do território por parte destas comunidades.

É também interessante observar a distância de TV3 em relação às amostras argáricas, mas a sua proximidade com a Motilla del Azuer, da cultura de Las Motillas. Contudo, é sem dúvida necessário um maior número de traços comparativos e de amostras populacionais para aprofundar esta problemática.

Os únicos graus de expressão de cúspides de Carabelli da amostra foram registadas para os dois indivíduos não adultos [2367] e [2368] recuperados do hipogeu [2471] - [2472], e no adulto feminino [1782] do hipogeu [1947] - [1948]. Seria pertinente realizar análises de DNA a estes dois primeiros, para averiguar uma possível relação de parentesco entre eles.

Por fim, ainda relativamente à análise morfológica de TV3, a elevada frequência de duas raízes nos caninos inferiores $(16,7 \%, \mathrm{n}=18)$ assim como 
da presença de fossa hipotrocânteriana nos fémures $(33,3 \%, n=18)$, uma vez que são elementos que podem ser derivados por parâmetros genéticos, podem ser encarados como indicador de uma comunidade reduzida e com tradições endogâmicas (Al OuMAOUI 2009:182; Silva 2002). No entanto, não se deve excluir a influência que determinados factores ambientais podem ter na expressão de alguns destes parâmetros, particularmente nos não dentários (KAUR et al. 2012).

No âmbito da análise paleopatológica, como já referido anteriormente, no indivíduo [2069] observou-se que a cabeça do fémur se encontra quase ao mesmo nível do grande trocânter. Esta morfologia atípica já foi anteriormente identificada no contexto pré-histórico Peninsular por Silva $(2002 ; 2003 ; 2012)$, nomeadamente nos indivíduos exumados do Tholos de Paimogo I, Cabeço da Arruda II, Cova da Moura e do Abrigo da Serra da Roupa (necrópoles do Neolítico Final/Calcolítico). Uma possível etiologia é um grupo de doenças associadas a um desenvolvimento ósseo defeituoso, denominadas de displasias esqueléticas (ORTNER 2003). A sua principal etiologia é genética, podendo ser tanto hereditário como resultado de uma mutação (AUFDERHEIDE \& RODRÍGUEZ-MARTín 1998). Porém, é também necessário ter em consideração que o ângulo do colo femoral é influenciado pela intensidade das actividades locomotoras durante a ontogenia (TRINKAUS 1993). Neste sentido, a morfologia atípica derivada do ângulo do colo femoral pode ter sido agravada devido a um esforço físico acentuado durante o desenvolvimento do indivíduo (SILVA 2002; 2012). Entre os possíveis diagnósticos, merece destaque a possibilidade de estarmos perante um possível caso de displasia esquelética (anomalias que afectam o crescimento ósseo) (SILVA 2002; 2012). Dentro deste grupo de anomalias, a mais provável seria a hipocondroplasia, uma forma menos grave deste tipo de doenças. É de origem genética e traduz-se por uma estatura baixa, aparência robusta, lordose lombar entre outras (SILVA 2002:200). Independentemente do diagnóstico não ser conclusivo, parece claro que esta devia afectar a mobilidade do indivíduo.

Como já referido anteriormente, no esqueleto [1781], adulto do sexo masculino, foi identificado um nódulo de Schmorl. Este tipo de nódulos está frequentemente relacionado com a formação de hérnias nos discos intravertebrais, causadas pelo esforço biomecânico intensivo e recorrente da coluna vertebral.

Ainda no mesmo indivíduo foi diagnosticado um possível caso de Osteochondritis dissecans (OD). Esta é uma lesão não inflamatória que leva à necrose parcial da região articular, geralmente causada por algum tipo de trauma e que conduz à disrupção normal do fluxo sanguíneo (AUFDERHEIDE \& RODRÍGUEZ-MARTÍN 1998). Geralmente ocorre mais frequentemente no sexo masculino (ORTNER 2003). Evidências de OD foram já encontradas em duas amostras do Neolítico Final/Calcolítico português de sepulturas colectivas: seis casos foram recuperados no Tholos de Paimogo I (cinco ossos de adulto e um não adulto), e um outro caso de adulto do Abrigo da Serra da Roupa (SILVA 2002; 2012). No entanto, este parece ser o primeiro caso português de OD na PréHistória recente que incide sobre um osso do tarso, sendo que, nas amostras acima mencionadas, a maior incidência desta lesão recai sobre as articulações do joelho e da anca (SILVA 2002; 2012).

No que diz respeito à lesão unilateral identificada no fémur direito do esqueleto [2032], foram propostos como diagnóstico diferencial um possível caso de epifisiólise superior do fémur, doença de Legg-Calvé-Perthes ou fractura. Uma vez que as alterações ósseas observadas entre a epifisiólise superior do fémur e a doença de Legg-CalvéPerthes tendem a sobrepor-se e persistir durante a idade adulta, chegar a um diagnóstico diferencial específico entre as duas pode ser difícil (ORTNER 2003). A epifisiólise superior do fémur é caracterizada pelo deslocamento da epífise proximal femoral por razões ainda não completamente conhecidas, embora alguns autores considerem que fractura induzida por um trauma ou por alguma actividade sejam as causas mais prováveis (WALDRON 2009). Ocorre geralmente durante a puberdade, e é reconhecida pela interrupção do fluxo sanguíneo entre a cabeça e o colo femoral, constituindo a osteonecrose e a artrose, sequelas tardias (WALDRON 2009). A doença de Legg-Calvé-Perthes é por sua vez caracterizada pela obstrução do fluxo sanguíneo da cabeça femoral que progressivamente leva a necrose vascular idiopática (WASTERLAIN \& UMBELINO 2014). Mais uma vez o trauma pode ser considerado uma das causas mais prováveis, e após a recuperação é típico observar que a cabeça femoral se torna mais achatada, o colo femoral mais curto e mais alargado, assim como se pode registar a presença de artrose secundária (ORTNER 2003; WALDRON 2009). A etiologia de fractura não deve ser refutada, apesar da análise radiológica não ter revelado nenhuma linha de fractura. Porém, estas podem ser reabsorvidas, situação plausível no presente, caso uma vez que se trata de uma lesão antiga que terá ocorrido muitos anos antes da morte do indivíduo [2032]. Uma vez que as áreas marginais de osteófitos estão localizadas mais na região da epífise capital femoral, e a cabeça do fémur não se encontra achatada ou tão porosa como seria de esperar na doença de Legg-Calvé-Perthes, o diagnóstico mais provável parece ser um possível caso de epifisiólise superior do fémur. Porém a deslocação da cabeça femoral típica desta osteocondrose não é facilmente visível, observação essa dificultada pelas alterações degenerativas severas presentes na extremidade proximal do fémur. O encurtamento do colo femoral seria um elemento adicional 
esperado em caso de osteocondrose, mas que não está presente nesta situação, assim como a preservação do ligamentum capitis femoris podem ser usados como argumentos para contrapor este diagnóstico.

No indivíduo adulto do sexo masculino [2365] - [2458] observaram-se evidências de uma fractura na região distal da ulna direita. Na diáfise do rádio direito deste indivíduo foi observado um arqueamento da diáfise que poderá estar associado ao trauma anterior. As fracturas nesta região podem ser causadas tanto por um trauma directo como por um indirecto, e levar à deslocação dos ossos (LOVELL 1997). Uma das possíveis causas para esta lesão pode ser a queda do indivíduo com as mãos estendidas (MAYs 1998:175). Uma outra interpretação, passa por considerar que a lesão tenha sido causada pelo impacto de um objecto na região do antebraço, levando à fractura e/ou deslocação da diáfise ulnar (LOVELL 1997). As fracturas isoladas na região distal da ulna estão geralmente associadas a traumas directos causados por um mecanismo contundente, onde o antebraço é usado para bloquear um impacto na cabeça ou no pescoço (DYMOND 1984: 408).

Outras evidências de lesões traumáticas foram identificadas em TV3, nomeadamente na fossa [2392], de onde foram exumados três indivíduos adultos (COELHO 2015). Neste contexto, o indivíduo adulto do sexo feminino [2324] apresenta uma fractura oblíqua não consolidada na diáfise da ulna esquerda, com formação de pseudoartrose (COELHO 2015). É possível extrapolar que, tal como no caso anterior, esta lesão possa ter sido causada ou pela queda do indivíduo com os braços estendidos, ou eventualmente por algum evento de violência interpessoal. Outros dois casos com sinais de lesões traumáticas foram identificados neste mesmo sepulcro, um caso na extremidade acromial de uma clavícula esquerda e um segundo caso num quinto metacarpo direito. Contudo, estes últimos dois casos provêm de contextos de ossos dispersos, pelo que não é possível associar a um determinado indivíduo.

$\mathrm{Na}$ região antero-superior da órbita esquerda do indivíduo adulto do sexo masculino [2007] observa-se alguma porosidade, possivelmente relacionada com cribra orbitalia, um indicador de stresse fisiológico. Até há pouco tempo esta patologia estava fortemente relacionada com a anemia. No entanto, estudos mais recentes alertam para que outras etiologias não devam ser descartadas no diagnóstico final, tais como infecções ou inflamações na região dos olhos (WAPLER et al. 2004, WALKER et al. 2009). Em comunidades coevas no contexto Peninsular este indicador tem sido registado em não adultos das comunidades argáricas nomeadamente um caso documentado num não adulto, com aproximadamente dois anos, da necrópole de La Illeta dels Banyets (El Campello, Alicante) (MIGUEL IBÁÑEZ 2001), outro em um não adulto de 12-16 meses da necrópole de Gatas (BUIKSTRA et al. 1991:272). Na necrópole de Cerro del Alcázar foram diagnosticados seis casos claros de cribra orbitalia, metade dos quais associados a indivíduos não adultos (ROBLEDO \& TRANCHO 2003:12), e na própria necrópole de El Argar foram registados mais dois casos, um num indivíduo com oito anos, e um segundo com 15 anos (KUNTER 1990:88 in BUIKSTRA et al. 1991:272). Em amostras portuguesas préhistóricas, este indicador é geralmente registado com uma frequência muito baixa (SILVA 2002).

O desgaste dentário oclusal dos indivíduos adultos da amostra de TV3 é de 3,78 (n=473). Os valores estão próximos dos resultados obtidos por Silva (2012:223) na análise de algumas necrópoles do Neolítico Final/Calcolítico Peninsular, onde as médias variam entre 3,10 e 4 (Tabela 7). Curiosamente, outras amostras da Idade do Bronze apresentam uma média de desgaste dentário inferior, nomeadamente na necrópole de cistas de Monte da Cabida 3, a média de desgaste é de 2,6 ( $\mathrm{n}=143)$, e na necrópole de Casas Velhas a média de desgaste é $2,8(\mathrm{n}=110)$ (GIL 2014)

Tabela 7 - Média de valores de desgaste dentário oclusal registados em várias amostras arqueológicas da pré-história recente em Portugal usando o método de Smith (1984) adaptado por Silva (1996)

Table 7 - Mean values of the dental wear registered in several archaeological samples of the recent pre-history in Portugal using the method Smith (1984) adapted by Silva (1996).

\begin{tabular}{|c|c|c|c|}
\hline Sitio arqueológico & Cronologia & Desgaste dentário oclusal & Referência \\
\hline Cabeço de Arruda I & Neolítico Final/Calcolítico & $3,89(\mathrm{n}=35)^{*}$ & Silva, 2012 \\
\hline Cova da Moura & Neolítico Final/Calcolítico & $3,65(\mathrm{n}=339)$ & Silva, 2012 \\
\hline Dólmen de Ansião & Neolítico Final/Calcolítico & $4,00(\mathrm{n}=41)^{*}$ & Silva, 2012 \\
\hline Paimogo I & Neolítico Final/Calcolítico & $3,51(\mathrm{n}=1097)$ & Silva, 2012 \\
\hline São Paulo II & Neolítico Final /Calcolítico & $3,86(\mathrm{n}=367)$ & Silva, 2012 \\
\hline Serra da Roupa & Neolítico Final/Calcolítico & $3,10(\mathrm{n}=60)^{*}$ & Gil, 2014 \\
\hline Monte da Cabida 3 & Idade do Bronze & $2,6(\mathrm{n}=143)^{*}$ & Gil, 2014 \\
\hline Casas Velhas & Idade do Bronze & $2,8(\mathrm{n}=110)^{*}$ & Presente texto \\
\hline Torre Velha 3 & Idade do Bronze & $3,78(\mathrm{n}=473)$ & \\
\hline
\end{tabular}


Para além do desgaste dentário foram encontradas evidências do uso não mastigatório dos dentes em TV3 o que pode ter contribuído para o aumento da média do desgaste oclusal da amostra. Estas foram encontradas em cinco indivíduos do sexo feminino [2051], [2203], [1799], [1575], [1714] e no adulto [1570] cujo sexo não foi possível determinar (Tabela 6). Estes padrões de desgaste podem ser causados pelo manuseamento de materiais fibrosos (tanto de origem animal como vegetal), usados em possíveis actividades quotidianas como a tecelagem, o uso ou produção de redes ou fios de pesca (MOLNAR 2008; LORKIEWICZ 2011) assim como no processamento de peles (Lous 1970). A fricção repetitiva exercida entre o objecto em causa e o dente pode levar à formação destes desgastes atípicos (ESHED et al. 2006). Curiosamente, na necrópole de Monte do Vale do Ouro 2, datada da Idade do Bronze, foram encontradas evidências semelhantes que também corroboram o uso não mastigatório dos dentes por indivíduos adultos (PEREIRA 2014). Infelizmente, estes restos dentários foram recuperados isolados não tendo sido possível determinar o sexo do indivíduo.

Semelhante ao que sucedeu com a análise da distribuição das cerâmicas, em TV3 o perfil demográfico associado a estes tipos de desgastes atípicos parece sugerir uma diferenciação laboral entre os sexos nesta comunidade, com algumas actividades possivelmente só desempenhadas pelo sexo feminino. Em alguns casos como o observado no indivíduo [1799], o uso dos dentes como ferramenta para a produção de corda, fio ou cestaria parece ser bastante clara. Outras hipóteses incluem o uso dos dentes em actividades piscatórias uma vez que existem recursos fluviais adjacentes a Torre Velha 3, os quais poderiam ter tido algum papel na subsistência desta comunidade. Contudo, dado o possível ênfase na pastorícia e o contexto geográfico da peneplanície alentejana, esta hipótese torna-se menos provável como a principal causa de formação destes desgastes atípicos. Análises de isótopos para inferir a dieta destes indivíduos poderiam contribuir para esclarecer esta problemática. Não obstante, a produção e a manipulação de corda ou de tecido parece ser a causa mais provável. No caso das evidências de desgaste severo na dentição posterior, como aquela que observámos no indivíduo [2051], o processamento de peles pode ser incluído no diagnóstico, uma vez que não se registam marcas claras do objecto que possa ter causado o desgaste. Em suma, apesar destas formas de desgaste estarem associadas ao uso dos dentes como ferramenta ou como uma "terceira mão", ainda não está claro se todas elas refletem o mesmo tipo de actividade laboral. Futuras análises ao microdesgaste dentário destes indivíduos poderão contribuir para conseguir uma melhor clarificação desta problemática, e nomeadamente no que se refere à identificação das actividades que terão estado na sua origem.
Entre as patologias orais, registaram-se lesões cariogénicas em $57 \%$ dos indivíduos adultos $(n=21)$, correspondendo a 5,85\% (29/495) dos dentes. Na mesma região do Baixo Alentejo, durante o Neolítico, as frequências de lesões cariogénicas estavam entre os 1,04\% (1/96) no hipogeu $5 \mathrm{em}$ Outeiro Alto 2 (Brinches, Serpa) (FERNANDES A 2013) e 4,76\% (1/21) no hipogeu 3 de Vale de Barrancas (Beringel, Beja) (FERnANDES P 2013). Entre o Calcolítico e a Idade do Bronze, a frequência destas lesões é 8\% (2/26) em Monte do Vale do Ouro 2 (Ferreira do Alentejo, Beja), 5\% (3/60) em Ribeira de S. Domingos 1 e 7,41\% (2/27) em Alto de Brinches 3 (PEREIRA 2014:103). Os valores de TV3 encontram-se assim enquadrados nos valores das comunidades do Calcolítico e da Idade do Bronze, às quais se associa uma dieta com mais hidratos de carbono decorrente de um aproveitamento mais intenso dos recursos resultantes da revolução dos produtos secundários. Em alguns casos, estes valores são superiores aos registados para as comunidades anteriores do Neolítico Final/ Calcolítico (SILVA 2002; 2012), onde a média da frequência de lesões cariogénicas registadas na necrópole do Cabeço de Arruda I é de 5,5\% ( $\mathrm{n}=2 / 35), 2,5 \%$ (1/40) no Dólmen de Ansião, 3,3\% $(n=12 / 361)$ em São Paulo II e 4,5\% $(n=3 / 67)$ em Serra da Roupa. Contudo, existem excepções como a necrópole da Cova da Moura com uma média de lesões cariogénicas de $8,2 \%(\mathrm{n}=27 / 331)$ e Paimogo I com uma média de $6,7 \%(\mathrm{n}=72 / 1073)$.

\section{CONSIDERAÇÕES FINAIS: AS PRÁTICAS FUNERÁRIAS E OS REFLEXOS DO QUOTI- DIANO DAS COMUNIDADES DO BRONZE PLENO DO SUDOESTE}

Outrora, o Bronze do Sudoeste foi um período conhecido a nível arqueológico e antropológico essencialmente pelos enterramentos em cista, muitas vezes sem restos osteológicos preservados, o que oferecia uma particular e evidente dificuldade para o conhecimento de vários aspectos destas populações, nomeadamente ao nível da antropologia funerária e da sua paleobiologia. A utilização de cistas como a forma de sepultura exclusiva deste período poderia ter sido questionada com a identificação da sepultura de Belmeque (SCHUBART 1974), no entanto, a singularidade da sua arquitectura e do seu espólio, levou a que na época fosse considerada um caso excepcional assim como a outras inferências que ainda hoje prevalecem parcialmente. Belmeque foi o primeiro hipogeu do II milénio a.C. a ser identificado no contexto nacional (SCHUBART 1971; SOARES 1994). Com um espólio votivo único e uma arquitectura funerária que então só encontrava paralelos no Sudeste peninsular, foi interpretado como revelando influências da cultura de El Argar.

Resgatada entre 2008 e 2009, a necrópole de hipogeus de Torre Velha 3 tem vindo a contribuir 
sistematicamente para a caracterização das comunidades do Bronze do Sudoeste. Anteriormente, já outros autores se debruçaram sobre vários elementos desta necrópole, desde a análise das estruturas funerárias, a vários aspectos do ritual fúnebre, do espólio associado e da sua datação radiométrica (ALVES et al. 2010), passando pelos rituais de comensalidade (PORFírIO \& SERRA 2010), pelo estudo dos artefactos metálicos (VALÉRIO et al. 2014) e pelas análises de sedimentos (FRADE et al. 2014).

$\mathrm{O}$ estado da arte actual não é peremptório para se afirmar que estamos perante uma comunidade claramente hierarquizada. Contudo, relativamente a este aspecto a variedade tipológica e o sincronismo das várias arquitecturas funerárias presentes (hipogeus, fossas e nichos) poderão ser considerados como elementos que indiciem a existência de alguma diferenciação ao nível do status social dos indivíduos. No entanto, o estado actual dos nossos conhecimentos sobre estas comunidades é ainda bastante parcelar e fragmentário para se avançar com interpretações definitivas relativamente a esta temática.

Por sua vez, a predominância de enterramentos individuais em hipogeus, alguns com sinais de reutilização, sugere que estes foram usados possivelmente como meio de divisão de núcleos familiares. Um dos exemplos mais claros encontra-se no hipogeu [2471] - [2472], onde os esqueletos [2367] e [2368] possuem indicadores dentários não métricos que indicam a sua afinidade biológica. Como refere Mário Varela Gomes (1994:135), na análise interpretativa dos resultados da necrópole de cistas de Alfarrobeira (S. Bartolomeu de Messines), as relações de consanguinidade destes grupos não eram necessariamente quebradas com a morte, mantendose a unidade da estrutura familiar através da separação dos indivíduos por grupos no ritual funerário.

A necrópole de hipogeus de TV3 apresenta ainda alguns pontos de contacto com o Sudeste Peninsular. Tal argumento é fundamentado pelas evidências ao nível da arquitectura dos hipogeus, da existência de oferendas cárneas e da presença de dois exemplares de taça com pé. Refira-se que estas últimas inserem-se numa tipologia que não encontra paralelos nos reportórios cerâmicos do Bronze do Sudoeste, apresentando, por sua vez, algumas semelhanças com a forma 7 argárica (SCHUBART 2004b).

Para além do que já se afirmou, as características de alguns objectos metálicos também o sugerem, nomeadamente quatro punções e um punhal que apresentam ligas de bronze com valores normalizados de estanho, $8-12 \% \mathrm{Sn}$. Estas percentagens são típicas de uma metalurgia do bronze desenvolvida e bem implementada, o que no caso do Sul de Portugal só acontece mais tarde, na Idade do Bronze Final, sendo assim é provável que as peças referidas sejam de origem exógena (VALÉRIO et al. 2014).
Contudo, no actual estado da arte, estas afinidades entre o Sudeste e Sudoeste Peninsular ainda só são visíveis na análise comparativa da cultura material. No que diz respeito à antropologia biológica, seriam necessários mais estudos para se poder chegar a resultados mais conclusivos. Assim sendo, como propostas para estudos futuros, além de eventuais análises de DNA, seria ainda pertinente aumentar o número de amostras comparativas ao nível da morfologia dentária. Além destas possibilidades, outra proposta seria a inclusão de análises de isótopos de estrôncio $\left({ }^{87} \mathrm{Sr}\right.$ e $\left.{ }^{86} \mathrm{Sr}\right)$ ao esmalte dentário e ossos dos indivíduos encontrados nesta necrópole, pois através do estudo destes elementos seria possível avaliar a mobilidade dos indivíduos (SLOVAK \& PAYTAN 2011).

Quanto às possíveis formas de subsistência e de práticas quotidianas, a existência, nos hipogeus, de oferendas cárneas de animais domesticados sugere que a criação de animais pudesse ser uma das principais actividades desta comunidade (PORFÍRIO \& SERRA 2010). Aquelas estão associadas a enterramentos de indivíduos adultos de ambos os sexos, sugerindo que ambos poderiam estar envolvidos nas actividades relacionadas directa ou indirectamente com a agro-pastorícia. No que diz respeito aos dados antropológicos, o achatamento e a robustez dos membros inferiores dos esqueletos em associação com as suas frequentes alterações degenerativas articulares e alterações da entese indicam que estes indivíduos exerciam um esforço físico quotidiano repetitivo, eventualmente relacionado com práticas agro-pastoris. A partir desta análise podemos avançar com a hipótese de que o aproveitamento extensivo da peneplanície alentejana para a agricultura e para a criação de gado, juntamente com a existência de contactos inter-regionais, obrigariam ao deslocamento de alguns indivíduos da comunidade.

A possível divisão laboral entre sexos também pode ser considerada. Alguns indivíduos adultos do sexo feminino apresentam evidências de um desgaste dentário atípico que sugere o uso dos dentes como ferramenta, ou seja, como "terceira mão". Falta ainda compreender se estas evidências correspondem a um ou a mais tipos de actividades laborais distintas. Contudo o manuseamento e a produção de corda ou fio (tanto de fibra animal como vegetal) são as actividades mais prováveis. Também os recipientes cerâmicos, assim como a grande maioria dos punções, aparecem associados mais frequentemente a enterramentos do sexo feminino (Fig. 12). Em ambos os casos, permanece a dúvida: estamos perante objectos exclusivos do quotidiano ou eles foram usados somente no âmbito do ritual funerário? Ou será ainda de entrar em consideração com uma terceira hipótese, mais provável até, terá sido a importância destes objectos para o dia a dia destas populações o elemento responsável pelo facto deles terem acompanhado o seu detentor até à sepultura? 


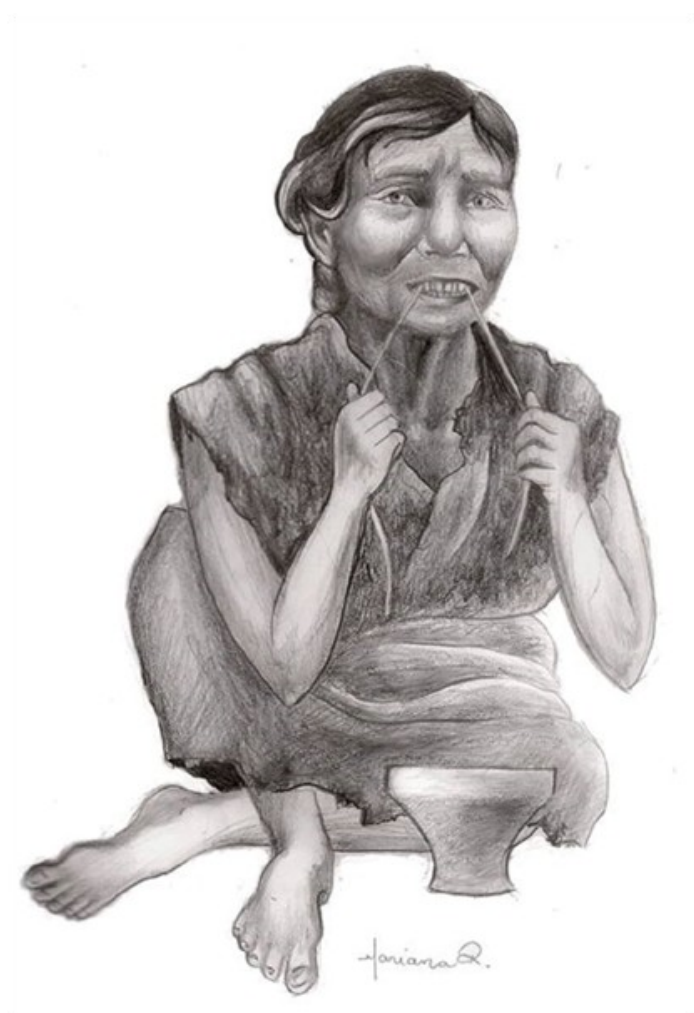

Fig. 12. Ilustração do uso de dentes como ferramenta por uma mulher adulta, segurando material fibroso para a cestaria, tecelagem ou redes de pesca (Desenhado por Mariana Rodi Thomaz, 2014).

Fig. 12. Illustration of an adult female using teeth has tools, holding fibrous material for making basketry, weaving or fish nets (Drawing by Mariana Rodi Thomaz, 2014).

\section{AGRADECIMENTOS}

Os autores gostariam de agradecer à Dr. ${ }^{\text {a }}$ Maria Teresa dos Santos Ferreira do Departamento de Ciências da Vida da Universidade de Coimbra por todo o apoio e esclarecimentos prestados durante todo o processo de análise laboratorial. Agradecemos também à Dr. ${ }^{a}$ Cleia Detry pelas informações relativas aos restos não humanos e à Teresa Rafael do Serviço de Radiologia do Centro Hospitalar da Universidade de Coimbra. Por último, agradecemos à Mariana Rodi Thomaz por ter disponibilizado a ilustração para ser usada neste trabalho.

\section{BIBLIOGRAFIA}

Al Oumaoui, I. 2009. Afinidades entre poblaciones antiguas en la Península Ibérica: antropología Dental. Editorial de la Universidad de Granada.

Alqahtani, S.J.; Hector, M.P. \& LiVERsidge, H.M. 2010. Brief communication: the London atlas of human tooth development and eruption. American Journal of Physical Anthropology, 142(3): 481-490.

Alves, C.; Costeira , C.; Estrela, S.; Porfírio, E. \& SERrA, M. 2009. Torre Velha 3. Relatório Final $\left(2^{a}\right.$ fase): Minimização de impactes sobre o património cultural decorrentes da construção da Barragem da Laje (Serpa). (Relatório inédito, IGESPAR) Lisboa.

Alves, C.; Costeira, C.; Estrela, S.; Porfírio, E. \& SERrA, M. 2012. Torre Velha 3 (Serpa): dados preliminares. Al-Madan. II Série. 17:31-38.
Alves, C.; Costeira, C.; Estrela, S.; Porfírio, E.; SerRA, M.; SoAres, A.M. \& Moreno-García, M. 2010. Hipogeus funerários do Bronze Pleno da Torre Velha 3 (Serpa, Portugal). O Sudeste no Sudoeste?!. Zephyrus. Revista de Prehistoria y Arqueologia, 66: 133-153.

Alves, C.; Estrela, S.; Serra, M.; Porfírio, E. 2014 Necrópole Tardo-Antiga da Torre Velha 3, Serpa (Baixo-Alentejo, Portugal). IV Encuentro de Arqueología del Sudoeste Peninsular, 68: 1929-1966.

Amo Y DE LA HERA, M. 1993. Formas e ritos funerários en las necrópolis de cistas del suroeste peninsular. SPAL: Revista de prehistoria y arqueologia de la Universidad de Sevilla, 2: 169-182.

Aranda JimÉneZ, G. \& Esquivel Guerrero, J.A. 2006 Ritual funerario y comensalidade en las sociedades de la edad del bronce del sureste peninsular: la cultura de El Argar. Trabajos de Prehistoria, 63 (2): 117-133

ARANDA JimÉnEZ, G.; MONTÓN SubÍAS, S.; SÁNCHEZRomero, M. \& Alarcón, E. 2009. Death and everyday life. The Argaric societies from Southeast Iberia. Journal of Social Archaeology, 9(2): 139-162.

Assis, S.S.D. 2007. A memória dos rios no quotidiano dos homens: contributo de uma série osteológica proveniente de Constância para o conhecimento dos padrões ocupacionais. Dissertação de Mestrado em Evolução Humana Coimbra, Faculdade de Ciências e Tecnologia, Universidade de Coimbra. Policopiado.

Aufderheide, A.C. \& RodrígueZ-Martín, C. 1998. The Cambridge Encyclopedia of Human Paleopathology. Cambridge University Press.

Baptista, L.; Pinheiro, R. \& Rodrigues Z. 2012. Espacialidades dos Cadáveres em Montinhos 6; Contributos para uma compreensão das Práticas Funerárias da Idade do Bronze do Sudoeste Peninsular. Actas do V Encontro de Arqueologia do Sudoeste Peninsular (Almodôvar, 18 a 20 de Novembro de 2010): $149-170$.

BROOKS, S. \& SUCHEY, J.M. 1990. Skeletal age determination based on the os pubis: a comparison of the Acsádi-Nemeskéri and Suchey-Brooks methods. Human Evolution, 5(3): 227-238.

BRUZEK, J. 2002. A method for visual determination of sex, using the human hip bone. American Journal of Physical Anthropology, 117(2): 157-168.

Buikstra, J. \& UbelaKer, D. 1994. Standards for data collection from human skeletal remains. Proceedings of a Seminar at the Filed Museum of Natural History (Arkansas Archaeology Research Series 44). Fayetteville Arkansas Archaeological Survey.

Buikstra, J.; Castro Martínez, P.; Chapman, R.W.; Gonzalez Marcen, P.; HoShOWer, L.; Lull, V.; PiCASO, M.; Risch, R. \& SANAHUJA YLL, E. 1991. La Necrópolis de Gatas. In: Anuario Arqueológico de Andalucía 1990: 261-276

Coelho, M. J. 2015. Do Calcolítico à Idade do Bronze: Contextos funerários e análise paleobiológica de restos osteológicos humanos exumados das fossas de Torre Velha 3 (São Salvador, Serpa). Dissertação de Mestrado em Biologia e Evolução Humanas. Coimbra. Departamento Ciências da Vida da Universidade de Coimbra. Policopiado. 
Costa C. \& BAPTisTA L. 2014. The inclusion of faunal remains in Bronze Age funerary practices in Southern Portugal. Montinhos 6 as a case study. In Detry, C.; Dias, R. (Coord.). Proceedings of the First Zooarchaeology Conference in Portugal: Held at the Faculty of Letters, University of Lisbon, 8-9 March 2012. British Archaeological Reports International Series: $33-46$

CRUBÉZY, E. 1988. Interactions entre facteurs bio-culturels, pathologue et caracteres discrets, Exemple d'une population médiévale: Canac (Aveyron). Dissertação de doutoramento em Medicina, Universidade de Montpellier.

CunHA, C. 2015. Crossing the River: The Dental Morphology of Chalcolithic Populations in the Middle Guadiana. Tese de Doutoramento em Antropologia, ramo de especialização em Antropologia Biológica. Coimbra. Departamento de Ciências da Vida da Universidade de Coimbra. Policopiado.

Cunha, C.; Silva, A.; Irish, J.; ScotT, R.; Tomé, T. \& MARQUEZ, J. 2012. Hypotrophic Roots of the Upper Central Incisors - a Proposed New Dental Discrete Trait. Dental Anthropology Journal, 25 (1): 8-14.

Dias, G. \& TAYLES, N. 1997. 'Abscess Cavity' - a misnomer. International Journal of Osteoarchaeology, 7 (5): $548-554$

DYMOND, I.W.D. 1984. The treatment of isolated fractures of the distal ulna. Journal of Bone \& Joint Surgery, 66(3): 408-410.

Eshed, V.; Gopher, A.; Pinhasi, R. \& Hershkovitz, I. 2006. Tooth Wear and dental pathology at the advent of agriculture: new evidence from the Levant. American Journal of Physical Anthropology. 130 (2): $145-159$.

Estrela, S.; Costeira, C.; Alves, C.; Porfírio, E. \& SERrA, M. 2012. Torre Velha 3 (Serpa): um novo ponto no mapa da Idade do Ferro do Sudoeste. Actas do V Encontro de Arqueologia do Sudoeste Peninsular (Almodôvar, 18, 19 e 20 de Novembro de 2010): 235-268.

Ferembach, D.; Schwidetzky I. \& Stloukal M. 1980. Recommendations for age and sex diagnoses of skeletons. Journal of Human Evolution 9: 517-549.

FERNANDES, A.I. 2013. Estudo Paleoantropológico dos remanescentes osteológicos do Núcleo $C$ do Outeiro Alto 2 (Brinches, Serpa, Portugal). Dissertação de Mestrado em Biologia e Evolução Humanas. Coimbra. Departamento Ciências da Vida da Universidade de Coimbra. Policopiado.

FERnANDes, P. 2013. Os Hipogeus de Vale de Barrancas 1 (Beringel, Beja) - Prácticas funerárias e análise antropológica dos restos ósseos humanos exumados. Dissertação de Mestrado em Biologia e Evolução Humanas. Coimbra. Departamento Ciências da Vida da Universidade de Coimbra. Policopiado.

FERREIRA, M.T. 2009. Relatório dos trabalhos de antropologia biológica desenvolvidos no âmbito da minimização de impactes no sítio da Torre Velha 3. (Relatório inédito, IGESPAR) Lisboa.

FERREIRA, M.T. 2014. O contributo da Antropologia para o conhecimento das práticas funerárias pré e protohistóricas do sítio de Monte da Cabida 3. Memórias d' Odiana, 2a série: 242-245.
FIDALGO, D. 2014. Contextos funerários e estudo antropológico dos restos ósseos humanos dos hipogeus de Torre Velha 3 (São Salvador, Serpa): Uma aproximação ao estudo das comunidades humanas do Bronze do Sudoeste. Dissertação de Mestrado em Biologia e Evolução Humanas. Coimbra. Departamento Ciências da Vida da Universidade de Coimbra. Policopiado.

FILIPE, V.; Godinho, R; Granja, R.; RIBEIRO, A \& VAleRA, AC. 2013. Bronze Age funerary spaces in Outeiro Alto 2 (Brinches, Serpa, Portugal): the hipogea cemetery. Zephyrus, 71: 107-129.

FINNEGAN, M. 1978. Non-metric variation of the infracranial skeleton. Journal of Anatomy, 125(1): 23-37.

Frade, J.C.; SoAReS, A.M.M.; CANDEIAS, A.; Ribeiro, M.I.M.; PonTE, T.R.N.; SERRA, M. \& PORFÍRIO, E. 2014. Beeswax and propolis as sealants of funerary chambers during the Middle Bronze Age in the South-Western Iberian Peninsula. In: Proceedings of the 39th International Symposium for Archaeometry, Centre for Archaeological Science, UK Leuven (2012): 141-145.

García SAnJuÁN, L.G. 2006. Funerary ideology and social inequality in the Late Prehistory of Iberian SouthWest (c.3300-850 cal BC). In: DíAZ-DEL-Río \& García Sanjuán, L.G. Social Inequality in Iberian Late Prehistory. Archaeopress, British Archaeological Reports: 149 - 169.

GIL, P.A.A. 2014. Necrópoles de Cistas na realidade do Sudoeste Peninsular durante o II a.C.: Praticas funerárias e análise antropológica dos restos ósseos humanos exumados das Necrópoles de Casas Velhas e Monte da Cabida 3. Dissertação de Mestrado em Biologia e Evolução Humanas. Coimbra. Departamento Ciências da Vida da Universidade de Coimbra. Policopiado.

Gomes, M.V. 1994. A necrópole de Alfarrobeira (S. Bartolomeu de Messines) e da Idade do Bronze no concetho de Silves. XELB: Revista de arqueologia, arte, etnologia e história, (2).

Gomes, S.; BAPtistA, L. \& Rodrigues, Z. 2013. Tradições de inumação durante a Idade do Bronze em Torre Velha 12 (Salvador, Serpa). In: JiMÉnEZ Ávila, J., Bustamante, M. \& GARcía CABEZAs, M. (Ed.) VI Encuentro de Arqueología del Suroeste Peninsular (Villafranca de los Barros, 4 - 6 Octobre de 2012). Mérida: Ayuntamiento de Villafranca de los Barros: 709-732.

Hauser, G. \& De Stefano, G.F. 1989. Epigenetic variants of the human skull. Stuttgart, E. Schweizerbartsche Verlagsbuchhandlung.

Kaur, J.; Choudhry, R.; RAHEJA, S. \& Dhissa, N.C. 2012 Non metric traits of the skull and their role in anthropological studies. Journal of Morphological Sciences, 29(4): 189 - 194

KERR, N.W. 1988. A method of assessing periodontal status in archaeologically derived material. Journal of Paleopathology, 2(2):67-78.

Kohli, A.; Pezzotto, S.M. \& Poletto, L. 2011. Hipercementosis Apicales y no apicales en raíces dentárias humanas. International Journal of Morphology, 29 (4): $1263-1267$.

LORKIEWICZ, W. 2011. Nonalimentary Tooth Use in the Neolithic Population of the Lengyel Culture in Central Poland (4600 - 4000 BC). American Journal of Physical Anthropology, 144(4): 538 - 551. 
Lous, I. 1970. The masticatory system used as a tool. Tandlaegebladet, 74(1):1-10.

Lovejoy, C.O.; MeindL, R.S.; PryzBCK, T.R. \& MensFORTH, R.P. 1985. Chronological metamorphosis of the auricular surface of the ilium: a new method for the determination of adult skeletal age at death. American Journal of Physical Anthropology, 68(1) 15-28.

Lovell, N.C. 1997. Trauma Analysis in Paleopathology. American Journal of Physical Anthropology, 104(s 25): 139-170.

LUKACS, J.R. 1989. Dental anthropology: methods for reconstruction dietary patterns. In: Iscan, M. \& Kennedy, K. (Coord.). Reconstruction of life from the skeleton. New York, Alan R. Liss Inc. 261-286.

MacLaughlin, S. 1990. Epiphyseal Fusion at the Sternal End of the Clavicle in a Modern Portuguese Skeletal Sample. Antropologia Portuguesa, 8: 59-68.

Mariotti, V.; FAcchini, F. \& Belcastro, M.G. 2004. Enthesopathies - Proposal of a Standardized Scoring Method and Applications. Collegium Anthropologicum, 28 (1): 145 - 159.

Mariotti, V.; FACChini, F. \& Belcastro, M.G. 2007. The Study of Entheses: Proposal of a Standardised Scoring Method for Twenty-Tree Entheses of the Postcranial Skeleton. Collegium Antropologicum, 31(1): 291-313.

MARTIN, R. \& SALlER, K. 1957. Lehrbuch der Anthropologie. Stuttgart: Gustav Fischer Verlag.

MAYS, S. 1998. The Archaeology of Human Bones. Routledge, London and New York.

MENDONÇA, M.C. 2000. Estimation of height from the length of long bones in a Portuguese adult population. American Journal of Physical Anthropology, 112: 39- 48.

Miguel IBÁÑEZ, M.P. 2001. Inhumaciones argáricas de la Illeta dels Banyets (El Campello, Alicante): aproximación paleopatológica. In: Actas de $V$ Congreso Nacional de Paleopatologia (Alcalá la Real, Jaén), 1999: 9-19.

Molnar, P. 2008. Dental Wear and Oral Pathology: Possible Evidence and Consequences of Habitual Use of Teeth in a Swedish Neolithic Sample. American Journal of Physical Anthropology, 136 (4): 423 - 431.

Moore, W.J \& CorbetT, E. 1971. The distribution of dental caries in ancient British populations. I Anglo Saxon Period. Caries Research, 5(2):151-168.

Nunes, S.; Corga, M.; Basílio, L.; Ferreira, M.T.; CoUTO, R.; Almeida, M. \& NeVES, M.J. 2007. Primeira notícia acerca das fossas escavadas na rocha do Casarão da Mesquita 4 (S. Manços, Évora). AlMadan, $\mathrm{II}^{\mathrm{a}}$ série, $\mathrm{n}^{\mathrm{o}} 15$. Adenda electrónica.

ORTNER, D.J. 2003. Identification of Pathological Conditions in Human Skeletal Remains. Academic Press, San Diego (USA).

PEREIRA, T. 2014. Enterramentos em fossa no distrito de Beja. Práticas funerárias e estudo dos vestígios osteológicos da Pré-história Recente. Dissertação de Mestrado em Biologia e Evolução Humanas. Coimbra. Departamento Ciências da Vida da Universidade de Coimbra. Policopiado.
Ponte, T.R.N.; SoAres, A.M.M.; AraÚJo, M.F.; Frade, J.C. Ribeiro, I.; Rodrigues, Z.; Silva, R.J.C. \& VAlÉRIO, P. 2012. O Bronze Pleno do Sudoeste da Horta do Folgão (Serpa, Portugal). Os Hipogeus Funerários. Arqueólogo Português, 5(2): 265-295.

PorfírIo, E. \& SERRA, M. 2010. Rituais funerários e comensalidade no Bronze do Sudoeste da Península Ibérica: Novos dados a partir de uma intervenção arqueológica no sítio da Torre Velha 3 (Serpa). Estudos do Quaternário, 6: 49-66.

PorfírIo, E. 2014. Arquitectura e práticas funerárias da Idade do Bronze no concelho de Serpa: o caso de Torre Velha 3. Antrope - série monográfica, n. ${ }^{\circ} 1$ : 250-268.

ReIMer, P.J.; BAIllie, M.G.L.; BARD, E.; BAYliss, A.; BECK, J.W.; BERTRAND, CH.J.H.; BlaCKWELl, P.G.; BUCK, C.E.; BURR, G. S.; CUtler, K.B.; DAMON, P.E.; EDWARDS, R.L.; FAIRBANKS, R.; Friedrich, M.; GUILDerson, Th.P.; HogG, A.G.; Hughen, K.A.; Kromer, B.; Mccormac, G.; Manning, S.; RAmSeY, Ch.B.; ReIMer, R.W.; Remmele, S.; Southon, J.R.; Stuiver, M.; Talamo, S.; TAYlor, F.W.; VAN Der Plicht, J. \& WeyHenMEYER, C.E. 2004. IntCal04 Terrestrial Radiocarbon Age Calibration, 0-26 cal Kyr BP. Radiocarbon, 46 (3): 1029-1058.

Rivero Galan, E. 1988. Análisis de las Cuevas Artificiales em Andalucía y Portugal. Universidade de Sevilla, Sevilla.

Robledo, B. \& Trancho, G. 2003. Análisis antropológico y condiciones de vida de la población argárica de Cerro del Alcázar. Universidad Complutense de Madrid. Madrid.

Rodrigues, Z.; Estrela, S.; Alves, C.; Porfírio, E.; SERRA, M. 2012. Os contextos funerários do Sítio de Alto de Brinches 3. In: Actas do V Encontro de Arqueologia do Sudoeste Peninsular, 73-83.

SANTOS, C.M. 2002. Estimativa da estatura a partir dos metatársicos. Dissertação de Mestrado em Medicina Legal. Coimbra, Faculdade de Medicina, Universidade de Coimbra.

SAUNDERS, S. 1978. The development and distribution of discontinuous morphological variation of human infracranial skeleton. Archaeological Survey of Canada, 81. Ottawa: National Museum of Man Mercury Series.

SCHAEFER, M.; Black, S. \& Scheuer, L. 2009. Juvenile Osteology. A Laboratory and Field Manual. Academic Press, Elsevier Inc.

SchubART, H. 1971. Acerca de la cerámica del Bronce Tardío en el Sur y Oeste peninsular. Trabajos de Prehistoria, 28(1): 153-182.

SCHUBART, H. 1974. Novos achados sepulcrais do Bronze do Sudoeste II. In Actas das II Jornadas Arqueológicas. Vol. II. Lisboa: Associação dos Arqueólogos Portugueses, 65-86.

SCHUBART, H. 1976. Relaciones Mediterráneas de la Cultura de El Argar. Zephyrus, 26-27: 331 - 342.

SchubART, H. 2004a. Das reiche Grab einer jungen Frau aus dem el argar-zeitlichen Fuente Álamo. Madrider Mitteilungen, 45:97-107. 
SCHUBART, H. 2004b. La cerámica argárica en la estratigrafía de Fuente Álamo: Campañas de 1977-1982, SPAL: Revista de prehistoria y arqueología de la Universidad de Sevilla, 13: 35-82.

ScOTT, G.R. \& TURner, C.G. 1997. The Anthropology of Modern Human Teeth: Dental Morphology and its Variation in Recent Human Populations. Cambridge University Press.

SilvA, A.M. 1995. Sex assessment using calcaneus and talus. Antropologia Portuguesa. 13: 107 -109.

SILVA, A.M. 1996. O hipogeu de Monte Canelas I (IV-III milénios A. C.): estudo paleobiológico da população humana exumada”. Provas de Aptidão Pedagógica e Capacidade Científica, Departamento de Antropologia, Faculdade de Ciências e Tecnologia da Universidade de Coimbra. Policopiado.

Silva, A.M. 2002. Antropologia Funerária e Paleobiologia das Populações Portuguesas (litorais) do Neolitico Final/Calcolitico". Tese de Doutoramento em Antropologia Biológica. Departamento de Antropologia da Faculdade de Ciências e Tecnologia da Universidade de Coimbra. Policopiado.

Silva, A.M. 2003. Portuguese Populations of the Late Neolithic and Chalcolithic Periods exhumed from Collective burials: an overview. Anthropologie XLI/12: $55-64$.

Silva, A.M. 2012. Antropologia Funerária e Paleobiologia das Populações Portuguesas (litorais) do Neolítico Final/Calcolítico". Fundação Calouste Gulbenkian. Fundação para a Ciência e a Tecnologia.

SlovaK, N.M.; Paytan, A. 2011. Applications of Sr Isotopes in Archaeology. In: BASKARAN, M. (Ed.). 2011. Handbook of Environmental Isotope Geochemistry. Springer-Verlag Berlin Heidelberg. 743 768.

SMITH, B. H. 1984. Patterns of molar wear in Huntergatherers and agriculturalists. American Journal of Physical Anthropology, 63(1): 39-56.

SMITH, B.H. 1991. Standards of human tooth formation and dental age assessment. In: KelLy, M.A. \& LARSEN, C.S. (Coord.). 1991. Advances in Dental Anthropology. New York, Wiley-Liss, Inc. 143-168.

SoARES, A.M.M. 1994. O Bronze do Sudoeste na margem esquerda do Guadiana. As necrópoles do concelho de Serpa. In: Actas das V Jornadas Arqueológicas (Lisboa, 1993). Lisboa: Associação dos Arqueólogos Portugueses, 2: 179-197.

SoAres, A.M.M.; SAnTos, F.J.C.; Dewulf, J.; Deus, M. \& ANTUNES, A.S. 2009. Práticas Rituais no Bronze do Sudoeste - Alguns Dados. Estudos Arqueológicos de Oeiras, 17: 433-456.

Steckel, R. H.; LARSen, C. S.; Sciulli, P. W. \& Walker, P. 2006. Data Collection Codebook. [Online]. The Global History of Health Project.

Tomé, T.; Silva, A.M. \& VAlerA, A.C. 2014. Bioantropologia da Pré-História recente do Baixo Alentejo: dados complementares do estudo de um conjunto de séries osteológicas humanas da região de Brinches (Serpa). VI Encuentro de Arqueologia del Sudoeste Peninsular: $853-875$.
TrinKAUS, E. 1993. Femoral neck-shaft angles of the Qafzeh-Skhul early modern humans, and activity levels among immature Near Eastern Middle Paleolithic hominids. Journal of Human Evolution, 25(5): 393-416.

Turner, C.; Nichol, C. \& ScOTT, R. 1991. Scoring Procedures for Key Morphological Traits of the Permanent Dentition: The Arizona State University Dental Anthropology System. In: Kelly, M. \& Larsen, C. (Coord.). Advances in Dental Anthropology. New York. Wiley-Liss, Inc.: 13-31.

VALERA, A.C. \& FILIPE, V. 2010. Outeiro Alto 2 (Brinches, Serpa): Nota Preliminar sobre um espaço funerário e socialização do Neolítico Final à Idade do Bronze. Apontamentos de Arqueologia e Património, 5: 4956

Valério, P.; Silva, R.J.C.; Ponte, T.R.N.; ARAúJo, M. \& SOARES, A.M.M. 2012. Estudo arqueometalúrgico das dádivas funerárias dos hipogeus do Bronze Pleno do Sudoeste da Horta do Folgão. (Serpa, Portugal). Estudos Arqueológicos de Oeiras, Actas do IX Congresso Ibérico de Arqueometria, 19: 203 208.

VALÉrio, P.; SOARES A.M.M.; ARAÚJO, M.F.; SilVA, R.J.C.; Porfírio, E. \& SERRA, M. 2014. Arsenical copper and bronze in Middle Bronze Age buria sites of Southern Portugal: the first bronzes in Southwestern Iberia. Journal of Archaeological Science, 42: $68-80$.

Waldron, T. 2008. Palaeopathology. Cambridge University Press.

WALKER, P.L.; BATHURST, R.R.; RICHMAN, R.; GJARDRUM, T. \& ANDRUSHKO, V.A. 2009. The Cause of porotic hyperostosis and cribra orbitalia: a reappraisal of the iron-defiency-anemia hypothesis. American Journal of Physical Anthropology, 139(2): 109-125.

WAPler, U.; CRUBÉZY, E. \& Schultz, M. 2004. Is cribra orbitalia synonymous with anemia? Analysis and interpretation of cranial pathology in Sudan. American Journal of Physical Anthropology, 123(4):333339 .

WAsterlain, S.N. \& UmBelino, C. 2014. Legg-CalvéPerthes disease and slipped femoral capital epiphysis in skeletal remains of the Mediaeval Necropolis of Santa Maria (Sintra, Portugal). Cadernos do GEEvH, 2(2): 27 - 39 .

WASTERLAIN, S.N. 2000. Morphé: análise das proporções entre os membros, dimorfismo sexual e estatura de uma amostra da colecção de esqueletos identificados do Museu Antropológico da Universidade de Coimbra. Dissertação de Mestrado em Evolução Humana. Coimbra, Departamento de Antropologia, Universidade de Coimbra. Policopiado. 